\title{
The Impact of Executives' Gender, Financial Incentives, and Shareholder Pressure on Corporate Social and Ecological Investments
}

\author{
Jochen Theis $\mathbb{D} \cdot$ Marvin Nipper (D)
}

Received: 25 February 2021 / Accepted: 26 October 2021 / Published online: 12 November 2021

(C) The Author(s) 2021

\begin{abstract}
Archival research suggests that female executives have an impact on corporate decision-making and generally finds positive associations between female board representation and Corporate Social Responsibility (CSR) performance. However, archival research does not reveal why female executives decide differently in the context of CSR. As this is our starting point, we conduct an experiment and examine executives' decision-making in terms of CSR investment. While female executives seem to be more oriented towards social and ecological practices, we find strong evidence that participants' real-world incentive program mainly drives their CSR decision-making. We also examine if selected gender-specific character traits (risk propensity, sustainability attitude, and empathy) cause gender differences in executives' CSR decision-making. In an exploratory analysis, we furthermore show that executives' risk propensity affects their CSR decision-making conditional on the level of shareholder pressure they face. Our study contributes to the literature on executives' decision-making and to the CSR literature by enhancing our understanding of determinants of executives' CSR decision-making.
\end{abstract}

Keywords Corporate Social Responsibility · Ecological Investments · CSR · Executives' Decision Making · Gender

Availability of data and material The dataset analyzed in this study is available from the corresponding author on reasonable request.

Code availability All calculations were conducted using Stata 14.2.

Jochen Theis

University of Southern Denmark, Universitetsparken 1, 6000 Kolding, Denmark

E-Mail: jot@sam.sdu.dk

Marvin Nipper $(\bowtie)$

University of Duisburg-Essen, Lotharstr. 65, 47057 Duisburg, Germany

E-Mail: marvin.nipper@uni-due.de 
JEL Classifications M12 $\cdot$ M14 $\cdot$ M41

\section{Introduction}

Just recently, 181 members of the Business Roundtable, a nonprofit association whose members are chief executive officers of major U.S. companies, signed a "Statement on the Purpose of a Corporation", which represents a shift from a strong shareholder orientation to a more modern stakeholder capitalism (Business Roundtable 2019; Gartenberg and Serafeim 2019). Two of the five pillars described in the statement are a commitment to socially oriented and sustainable business practices. The statement follows on peaked public concern about climate change and its effects on society and increased pressure of shareholders and governments demanding firms to be socially responsible and to lower their ecological footprint (Basu and Palazzo 2008; Lin-Hi and Müller 2013; Luo et al. 2017; Henderson 2018).

While management is generally responsible for the implementation of a firm's CSR activities (Petrenko et al. 2016), the board also has a fundamental role in serving as a link to the external environment by representing a broad range of stakeholders and considering CSR issues in a firm's strategic agenda (Hillman et al. 2000; Wang and Dewhirst 1992). In this context, a substantial body of archival research suggests that female board members and female managers are more willing to encourage firms' stakeholder orientation and CSR performance than their male counterparts (Francoeur et al. 2019, 2008; Glass and Cook 2018; Glass et al. 2016; Hafsi and Turgut 2013; Harjoto et al. 2015). ${ }^{1}$ However, CSR research has not yet delivered conclusive evidence for a causal inference between female board and management representation and CSR performance (Smith 2018). Also, there is a lack of insights into which character traits and factors influence executives' CSR decision-making and why archival research finds differences between female and male executives (Wang et al. 2016). While some studies suggest that executives' incentive programs and the level of shareholder pressure are relevant determinants of firms' CSR activities (e.g. Beddewela and Fairbrass 2016; Dam and Scholtens 2013; Flammer et al. 2019), their effect on executives' individual CSR decision-making has not yet been examined by empirical studies.

Thus, we create an experimental investing scenario in which we observe executives' CSR decision-making on short-term profit maximization versus improvement of social/ecological standards under a restrained budget. We naturally measure participants' gender, record participants' real-world incentive structure, and manipulate shareholder pressure. Additionally, we capture participants' risk propensity, attitude towards sustainability, and empathy as these character traits are used as an explana-

\footnotetext{
1 Archival research either analyzes the association between female members of the board of directors or female members of the top management team and CSR performance. We employ the term "executives" because we generally examine gender-specific effects on CSR investment decisions and address both directors and managers as both the board of directors and top management are involved in a firm's CSR activities. Therefore, our results and implications apply to executives in general, which includes managers and directors.
} 
tion in many archival studies that find positive effects of female executives' on CSR performance. Our resulting experimental design enables us to examine gender differences in CSR decision-making while observing the role of incentives, shareholder pressure, and relevant character traits.

We draw upon psychological concepts and, in line with the large body of archival research, predict that female executives are generally more willing to sacrifice shortterm financial return to improve social/ecological standards when making investment decisions than male executives (Hypothesis 1a). We find weak statistical evidence that this relationship holds. We complement our analyses with a structural equation model (SEM) explicitly considering individual character traits (risk propensity, attitude towards sustainability, and empathy) as potential mediators, which allows a more nuanced analysis (Hypotheses 1b1-1b3). We find a strong effect of gender on the considered character traits, but no statistically significant effect of these character traits on CSR decision-making. Furthermore, as we capture participants' real-world incentive programs, we are able to analyze how this affects their CSR decisionmaking in our experiment. We find strong statistical evidence that, as the relevance of achieving financial goals in participants' real-world incentive program increases, participants focus more on short-term profit maximization in our experimental setting (Hypothesis 2). Therefore, we conclude that a certain type of behavior, which is promoted through participants' real-world incentive program, also transfers to the decisions made by participants in our experiment.

Additionally, since there is an ongoing debate in the empirical research about whether a firm's financial performance determines its CSR efforts (Arora and Dharwadkar 2011; Flammer and Ioannou 2021; Nelling and Webb 2009), we manipulate shareholder pressure (high vs. low) through shareholder satisfaction and the relative financial performance of our hypothetical firm in our experiment and observe if this affects executives' CSR decision-making (Hypothesis 3). We find that our manipulation does not affect executives' CSR decision-making. Finally, in an additional exploratory analysis, we find that risk propensity in connection with our shareholder pressure manipulation affects executives' CSR decision-making (Research Question 1).

Our study makes important contributions to the CSR literature and the literature on executives' decision-making by advancing our understanding of gender effects in managerial decision-making in the CSR context. With our experimental analysis, we can generally confirm a positive impact of female executives on firms' CSR performance. Although we find that the character traits, which are used extensively in archival studies to explain positive effects of female executives on firms' CSR performances, are gender-dependent, we do not find any effects of these character traits on executives' CSR investment decisions. Our analyses provide further interesting insights that might help to explain inconclusive findings of prior archival studies. As we find that executives' real-world incentive program plays a key role in explaining executives' CSR decision-making, we contribute to a growing stream of literature on CSR decision-making (Wang et al. 2016) by outlining that it is essential to control for executives' incentive programs to derive valid inferences. Additionally, our study is of practical importance. By emphasizing the positive impact of female executives on firms' CSR performance, our study also offers implications for poli- 
cymakers and for firms themselves, which will continue to face public and investor pressure to expand their social and ecological activities and, therefore, must adapt their corporate decision-making to address all stakeholder concerns. The results of our study imply that firms that intend to transform their business to adapt to the increased challenges of sustainability and social compliance need to make sure that their incentive programs sufficiently emphasize the achievement of sustainability goals.

Our paper proceeds as follows. In Sect. 2 we discuss related research and develop our hypotheses. Sect. 3 describes our methodology, while Sect. 4 discusses our results. Sect. 5 concludes our paper.

\section{Related Research and Hypotheses Development}

Over the past two decades, there has been a vivid debate about women's representation in top executive teams and its effect on a firm's decision-making (Dezsö and Ross 2012; Terjesen et al. 2009). Research has examined the impact of female executives on corporate decisions, such as financing, investment, reporting, and mergers and acquisitions (e.g., Francis et al. 2015; Huang and Kisgen 2013; Ibrahim et al. 2009; Levi et al. 2008; Mohan and Chen 2004). Evidence shows that decisions made by female executives can differ from those made by male executives.

Due to high levels of investor, public, and media attention, a firm's decision regarding its involvement in socially and environmentally responsible business practices is currently one of the most critical it must make and introduces new challenges to its leadership (Haney et al. 2020). Studies find that addressing social issues and the improvement of corporate social performance entails positive investor reactions and is perceived as a competitive advantage (Cordeiro and Tewari 2015; Flammer 2018; Kunz 2020; McWilliams et al. 2006). As CSR is therefore a highly relevant topic for almost all firms, research has also examined the role of gender diversity on CSR performance. Archival research linking female board and/or top management representation and CSR performance generally finds a positive association (e.g. Francoeur et al. 2019, 2008; Glass and Cook 2018; Glass et al. 2016; Hafsi and Turgut 2013; Harjoto et al. 2015).

However, archival studies on the relationship between female board and management representation and CSR are subject to some methodological challenges. Kato and Kodama (2018) find a delayed but positive effect of firms' CSR performance on workplace gender diversity, which indicates a possible reverse causality in the connection between gender diversity and CSR. It seems plausible that firms with a strong CSR performance also focus more on their public reputation and thus foster a higher female representation on management and oversight board (Brieger et al. 2019). Also, both the trend for more women in executive positions and the increased awareness of firms' social and ecological responsibility arose simultaneously. Therefore, archival studies might also just capture this simultaneous and continuous increase of female executives and CSR awareness. Consequently, archival CSR research has not yet delivered conclusive evidence for a causal inference between female board and management representation and CSR performance (Smith 
2018). Above that, research has not yet empirically examined which specific character traits are responsible for the gender differences when it comes to CSR decisionmaking.

Prior studies show that executives' personal characteristics and beliefs affect their decision-making, also with respect to CSR activities (e.g. Agle et al. 1999; Chin et al. 2013; Hoffmann and Meusburger 2018; Wally and Baum 1994). Research focusing on gender differences often draws on the work of Eagly (1987) and Eagly and Wood (1991) to explain differences between men and women and their respective roles in a corporate environment. According to their social role theory, women, through their role induced by society, develop more communal qualities (they are generous, socialoriented, concerned with others, etc.). This means that they are more socially skilled, emotionally sensitive, value personal relationships more, and are more oriented to others' welfare. In contrast, men display more agentic qualities (they are ambitious, self-directed, aimed at personal development, etc.) and focus on their own rewards, as they are assigned to social roles that demand these character traits. Consequently, through this societal selection, women's and men's social behaviors differ.

Also, Gilligan $(1977,1982)$ argues that based on their early childhood experiences, women and men utilize different procedures for making moral decisions and that women have a higher care orientation, which is characterized by a focus on long-term relations and responsiveness to the needs of others. However, empirical evidence of the differences between women and men regarding moral reasoning is ambiguous. Jaffee and Hyde (2000) find only sparse evidence in their meta-analysis that men and women differ in terms of care reasoning or justice reasoning, a finding supported by Forte (2004). In contrast, there is empirical evidence that women have a more long-term orientation (Fetchenhauer and Rohde 2002), which is supported by Embrey and Fox (1997) and Stewart (2018) in an investment context, and a higher social orientation (Croson and Buchan 1999).

Hence, as executives' personal characteristics and beliefs affect their decisionmaking, it may not be mere gender affiliation that explains gender differences in CSR decision making, but rather specific character traits. Inter alia, Glass and Cook (2018) use risk aversion to explain gender differences in business practices related to CSR. There is a large body of prior research that finds women to be more riskaverse than men (e.g. Croson and Gneezy 2009; Eckel and Grossman 2002), which also holds for financial decision-making and for C-level executives (Faccio et al. 2016; Huang and Kisgen 2013; Powell and Ansic 1997). In contrast, Adams and Funk (2012) document that female directors are more risk-loving than their male counterparts and highlight that this finding differs from studies of the general population. We analyze executives' decision-making in an investment context. Therefore, we identify risk propensity as one of our gender-dependent character traits possibly affecting executives' decision-making in terms of CSR. More specifically, related insights from prior research would imply that individuals with lower (higher) risk propensity are more (less) willing to invest in CSR. This is because CSR may function as reputation insurance against management lapses (e.g., Werther and Chandler 2005; Minor and Morgan 2011) and can lead to greater organizational resilience to systematic shocks (e.g., Sajko et al. 2021; Shiu and Yang 2017). However, explicit 
theory or empirical evidence regarding the association between risk propensity and executives' decision-making in terms of CSR is largely missing.

Archival research on female board and/or top management representation and CSR performance often draws on the works of Eagly (1987), Eagly and Wood (1991), and Gilligan $(1977,1982)$ to motivate gender differences in terms of CSR, highlighting that women are more long-term and socially orientated than men (see for example Boulouta 2013; Francis et al. 2015; Francoeur et al. 2019; Glass and Cook 2018). From this line of research, we derive empathy and the attitude towards sustainability as two possible mediators of a gender effect on CSR decision-making. Eagly and Wood (1991) and Gilligan (1977, 1982) describe that, based on their childhood experiences and social roles, women are more concerned with the welfare of others and have a more long-term orientation than men (see also Croson and Gneezy 2009; Fetchenhauer and Rohde 2002). Investments in sustainability are generally considered long-term (Porter and Miles 2013), and the attitude towards sustainability explains executives' CSR decision-making (Adomako et al. 2021). As long-term orientation seems to be more prominent in women, the attitude towards sustainability might also be gender-dependent. Thus, we examine if the attitude towards sustainability affects executives' CSR decision-making. Additionally, CSR investments result in welfare for others (Dickson and Chang 2015). As empathy constitutes the concern for others' welfare and, according to the literature, seems to be gender-dependent, we also capture executives' empathy and examine the impact of empathy on executives' CSR decision-making.

Consequently, we expect that the three outlined character traits rather than mere gender affiliation influence executives' CSR decision-making. However, these character traits might only partially capture the effects of gender affiliation on CSR decision making, as there might be other character traits that are gender-dependent and related to CSR decision making. Hence, to begin with, we formulate the following baseline Hypothesis 1a (H1a), which is derived from the archival evidence of a positive association between gender and CSR performance, and reads as follows:

Hypothesis 1a Female executives are more willing to sacrifice short-term financial return to improve social/ecological standards when making investment decisions than male executives.

Furthermore, as already argued, we expect that risk propensity, attitude towards sustainability, and empathy are gender-dependent and related to CSR decision-making because specific character traits rather than mere gender affiliation should affect executives' CSR decision-making. More specifically, based on the above-mentioned literature, we predict that female executives are more risk-averse, have a stronger attitude towards sustainability, and are more empathetic compared to male executives. We also expect that more empathy and a higher attitude towards sustainability lead to executives spending more on CSR. Yet, as we are not able to formulate a directed hypothesis for risk propensity based on the literature, we formally state our three Hypotheses 1b1-1b3 (H1b1-H1b3) for risk propensity, attitude towards sustainability, and empathy uniformly undirected, as follows: 
Hypothesis 1 b1 Risk propensity mediates the effect of gender on the investment decision to sacrifice short-term financial return to improve social/ecological standards.

Hypothesis 1 b2 Attitude towards sustainability mediates the effect of gender on the investment decision to sacrifice short-term financial return to improve social/ ecological standards.

Hypothesis $1 \mathrm{b3}$ Empathy mediates the effect of gender on the investment decision to sacrifice short-term financial return to improve social/ecological standards.

Incentive programs play a pivotal role in today's business world (Antón et al. 2020). Bonner et al. (2000) underline the prevalent importance of incentives not only for management accounting in general but also for experimental research. Furthermore, incentives are widely used to direct management's efforts to comply with stakeholders' interests and the inclusion of CSR criteria in executives' compensation schemes has recently become more prevalent (Flammer et al. 2019). Research has found various effects of incentives on executives' decision-making, for example with regard to innovation, performance, and earnings management (Bergstresser and Philippon 2006; Bonner et al. 2000; Makri et al. 2006). In a CSR context, Fabrizi et al. (2014) find that the split between monetary and non-monetary incentives of CEOs affects a firm's CSR efforts, while Boone et al. (2020), within their theoretical framework, explain that CEOs social values and the incentivizing context play an important role when explaining CSR decision-making. Hence, incentive programs should have a significant influence on executives' CSR decision-making. Specifically, we expect that programs with a stronger focus on financial goal achievement lead to executives focusing on short-term financial performance, while programs with a stronger focus on sustainable goal achievement encourage executives' CSR spending (Flammer et al. 2019). Furthermore, we argue that, due to spillover effects, executives' real-life incentive program affects their general CSR decision-making, which then also translates to our experiment (Huang and Murad 2020; Pierce et al. 2016). Applied to our experiment, this would mean that greater relevance of financial goals achievement in executives' incentive program leads executives' to focus more on short-term financial return when making the experimental CSR investment decisions. Consequently, we formally state the following Hypothesis 2 (H2):

Hypothesis 2 Greater relevance of financial goals achievement in executives' incentive program reduces executives' willingness to sacrifice short-term financial return to improve social/ecological standards when making investment decisions.

In recent years, public attention to firms' involvement in socially and environmentally responsible business practices has risen, while investors with a focus on socially and ecologically responsible investments have gained prominence and increased their activism (Boiral et al. 2017; Michelon and Rodrigue 2015). Research shows that external pressure, such as shareholder concentration or regulatory and institutional pressure, can influence a firm's CSR activities (Beddewela and Fairbrass 
Fig. 1 Structure of hypotheses

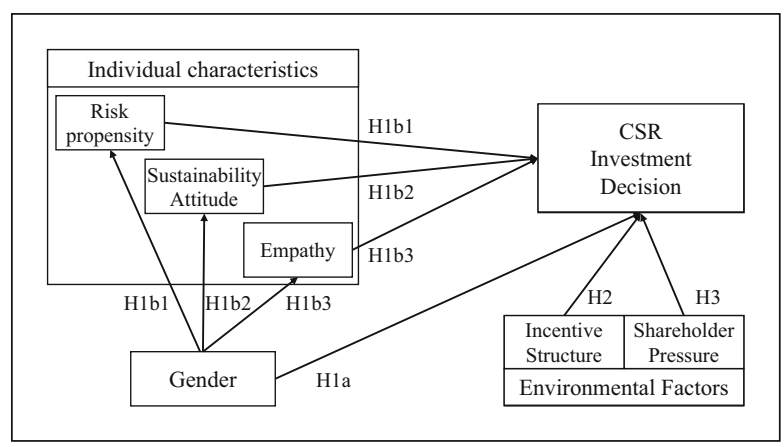

2016; Bryant et al. 2020; Dam and Scholtens 2013). More specifically, studies suggest that firms tend to respond to shareholder activism on sustainability issues with an increase in sustainability performance (Grewal et al. 2016; Harvey and Pearson 2018); this association is, however, conditional on the shareholder activists' status and their reputation to threaten the firm (Perrault and Clark 2015).

In our study, we want to investigate a different type of shareholder pressure where a firm's response in terms of executive CSR decision-making seems less intuitive: shareholder pressure that originates from a firms' financial performance. While it may seem reasonable to assume that a firms' financial performance has an influence on its ability and willingness to engage in (potentially costly) CSR, evidence in this regard is inconclusive. On the one hand side, Arora and Dharwadkar (2011) document that firms that exceed their aspired performance targets show increased CSR efforts. In this regard, Nelling and Webb (2009) find some evidence for a positive association between a firm's stock returns and specific aspects of CSR performance, such as employee relations. On the other hand side, Flammer and Ioannou (2021) report that firms that were adversely affected by the sharp increase in the cost of credit during the financial crisis maintained their CSR investments. Thus, they do not find an effect of decreased financial performance on CSR efforts.

In order to contribute to the debate about the effect of financial performance on CSR efforts, we manipulate shareholder pressure (high vs. low) through shareholder satisfaction and the relative financial performance of our hypothetical firm (see following sections for details). While we recognize the findings of Flammer and Ioannou (2021), we use the findings of Nelling and Webb (2009) and in particular Arora and Dharwadkar (2011) to posit a positive association between financial performance and CSR performance, leading to the following Hypothesis 3 (H3):

Hypothesis 3 Under high shareholder pressure executives are less willing to sacrifice short-term financial return to improve social/ecological standards when making investment decisions.

Fig. 1 illustratively summarizes our hypotheses. 


\section{Method}

\subsection{Participants}

We analyze the decision-making of executives in an experimental setting recruiting participants from a private survey company. ${ }^{2}$ Survey companies have been used to recruit high-level business managers in a number of prior studies (e.g. Arnold et al. 2012; Hannah et al. 2014; Johnson et al. 2020a; see also Brandon et al. (2014) for a comparison of participant recruitment services) and Walter et al. (2019) find that results drawn from commercial online panel data are generally suitable for applied psychological research.

We specified to the survey company that we wanted to recruit experienced executives residing and working for companies in the United States (U.S.). To ensure that participants met our criteria, we implemented several screening questions in our survey. We asked participants whether they work for a for-profit organization and only participants that affirm continued with the survey. Also, we asked participants in which industry they work. Participants who selected "Finance (Banks, Insurances, etc.)" automatically exited the survey. We also asked participants in which domain they primarily work and accepted only participants with the following backgrounds: Governance, Strategy, Finance, Accounting, Operations/Production. ${ }^{3}$ We also asked participants if they are a member of the board of directors, executive board, senior management, mid- or lower-level management of their organization. Without further screening, we only accepted participants that belong to either board of directors, executive board, or senior management. Participants that belong to mid- or lower-level management were additionally asked how frequently they are involved in significant investment decisions (e.g. about opening a new factory, production line, office, store or alike) and only passed this screening questions if they answered "sometimes", "often" or "very often". Additionally, to ensure that participants who generally met our criteria paid attention to our survey questions, we included one attention check later in the experiment and asked participants to select the response option "strongly disagree" if they pay attention. ${ }^{4}$ Participants who failed to answer the attention check correctly were also screened out, automatically exited the survey, and did not receive compensation. In total, 533 participants entered our survey and 123 passed all our screening questions. ${ }^{5}$ Thus, our final sample consists of responses from 123

\footnotetext{
2 The survey company is EMPanel Online (see https://empanelonline.com/) located in Flowery Branch, Georgia. The data from our survey is available upon request. Our experimental design meets the requirements for using human subjects in experiments at the university where the corresponding author is located and was approved.

3 The other options were Marketing, Sales, Human Resources, Research and Development, and Other domain not mentioned. Participants who selected one of these domains automatically exited the survey.

4 This attention check was predetermined by the private survey company.

5 Participants who did not meet our screening criteria or did not pass the attention check automatically exited the survey. Thus, we only have fragmentary data about these participants.
} 
Table 1 Descriptive statistics for our sample of 123 participants

\begin{tabular}{|c|c|c|c|c|c|c|c|c|c|}
\hline \multirow{2}{*}{$\begin{array}{l}N=123 \\
\text { Participants }\end{array}$} & \multicolumn{4}{|c|}{ Females $(N=43)$} & \multicolumn{4}{|c|}{ Males $(N=80)$} & \multirow{2}{*}{$\begin{array}{l}\text { t-test } \\
p \text {-value }\end{array}$} \\
\hline & Mean & StD & Min & $\operatorname{Max}$ & Mean & StD & Min & Max & \\
\hline $\begin{array}{l}\text { CSR Invest- } \\
\text { ment }\end{array}$ & 18.65 & 7.00 & 0 & 30 & 19.04 & 4.61 & 0 & 30 & 0.714 \\
\hline $\begin{array}{l}\text { Duration } \\
\text { (Seconds) }^{\mathrm{a}}\end{array}$ & 755.71 & 386.15 & 261 & 2022 & 683.53 & 392.03 & 194 & 2824 & 0.351 \\
\hline Age (Years) & 43.37 & 13.18 & 23 & 79 & 40.68 & 7.73 & 23 & 66 & 0.155 \\
\hline Tenure (Years) & 10.09 & 9.60 & 1 & 43 & 8.48 & 5.15 & 1 & 28 & 0.233 \\
\hline Listed (\%) & 0.44 & 0.50 & 0 & 1 & 0.73 & 0.45 & 0 & 1 & $0.002 * * *$ \\
\hline $\begin{array}{l}\text { Financial Goals } \\
(\%)\end{array}$ & 46.35 & 27.95 & 0 & 100 & 36.15 & 18.15 & 0 & 100 & $0.016^{* *}$ \\
\hline $\begin{array}{l}\text { Sustainab. } \\
\text { Goals }(\%)\end{array}$ & 18.16 & 16.99 & 0 & 75 & 26.56 & 15.53 & 0 & 100 & $0.007 * * *$ \\
\hline $\begin{array}{l}\text { Pers. Dev. } \\
\text { Goals }(\%)\end{array}$ & 25.56 & 20.58 & 0 & 90 & 24.3 & 12.70 & 0 & 70 & 0.676 \\
\hline $\begin{array}{l}\text { Tenure in cur- } \\
\text { rent Role }{ }^{b}\end{array}$ & 9.16 & 10.18 & 1 & 45 & 5.70 & 4.31 & 1 & 28 & $0.011 * *$ \\
\hline $\begin{array}{l}\text { Risk } \\
\text { propensity }\end{array}$ & 2.58 & 0.78 & 1.25 & 5 & 3.50 & 0.90 & 1.5 & 5 & $<0.001 * * *$ \\
\hline $\begin{array}{l}\text { Sustainability } \\
\text { attitude }^{c}\end{array}$ & 3.35 & 0.57 & 1.97 & 4.53 & 3.04 & 0.34 & 2.53 & 4.09 & $<0.001 * * *$ \\
\hline Empathy $^{\mathrm{c}}$ & 3.64 & 0.52 & 1.93 & 4.86 & 3.46 & 0.36 & 2.57 & 4.71 & $0.021 * *$ \\
\hline
\end{tabular}

Tenure captures how many years' participants have been with their current company. Listed indicates what percentage of participants' employers are public companies. The variable Financial Goals shows what percentage of participants' real life yearly salary is attributable to achieving financial goals, while the variable Sustainability Goals shows the corresponding percentage that is attributable to achieving sustainability goals and the variable Personal Development Goals shows the respective percentage attributable to participants' personal development goals

$* p<0.10 ; * * p<0.05 ; * * * p<0.01, p$-values are based on a two-tailed test

${ }^{a}$ Our survey tool has recorded five female- and one male participants with a duration of $-1 \mathrm{~s}$. We excluded these observations from the duration statistics

${ }^{b}$ Four male participants did not answer our question about their tenure in their current professional role leaving us with 43 responses of female participants and 76 responses of male participants

${ }^{\mathrm{c}}$ Risk propensity, sustainability attitude, and empathy are based on the risk-taking propensity subscale of the domain-specific risk-taking (DOSPERT) scale (Markiewicz and Weber 2013), the Environmental Attitudes Scale (EAS) (Ebenbach et al. 1998), and the empathy subscales developed by Davis (1980) respectively. These instruments use Likert-scales with different ranges. Thus, we linearly transformed each scale to the range of 1 to 5, with 1 indicating low risk propensity, sustainability attitude, and empathy and 5 indicating high risk propensity, sustainability attitude, and empathy

\section{participants. ${ }^{6}$ These participants were randomly assigned to one of our experimental conditions.}

We paid \$25 per completed survey to the survey company, of which participants earned a fixed portion based on what they agreed on with the survey company.

\footnotetext{
6 Of our participants, 46 are a member of the board of directors, 39 belong to an executive board, 57 belong to senior management, and 21 belong to mid- or lower management. Multiple choices were possible and some participants indicated that they belong to e.g. board of directors and executive board or senior management and board of directors.
} 
a Revenue of participants' employer. $\mathrm{N}=122$.

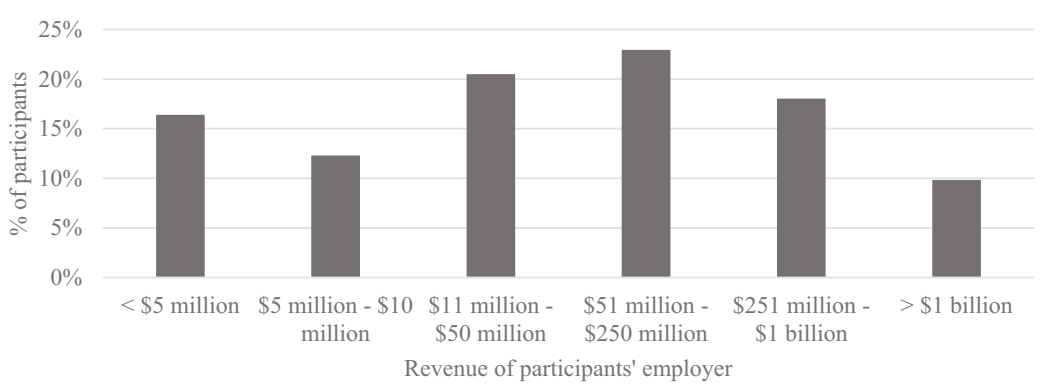

b Number of employees of participants' employer. $\mathrm{N}=123$.

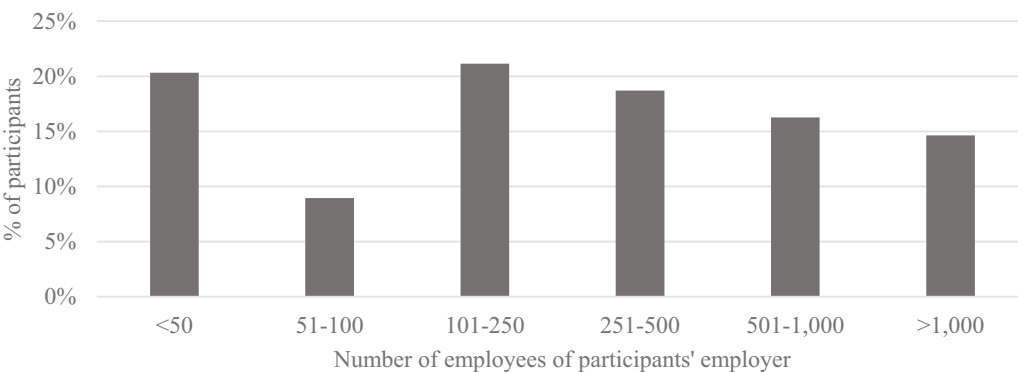

C Range of participants' annual fixed salary. $\mathrm{N}=108^{\ddagger}$.

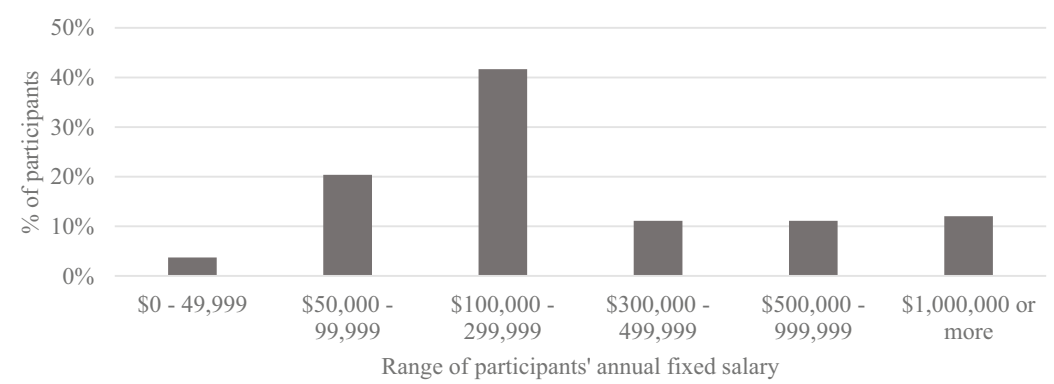

$\dagger$ One participant decided not to answer this questions

$\stackrel{5}{5}$ Fifteen participants answered that they only receive a variable compensation and thus, were not asked to indicated the range of their annual fixed salary.

Fig. 2 Participant statistics. Panel a displays the annual revenues of participants' employers. Panel b shows the number of employees for participants' employers and Panel $\mathbf{c}$ presents participants' annual fixed salary 
Based on their decisions during our experiment, participants could earn up to $\$ 3.00$ as markup. Table 1 summarizes relevant statistics about our participants and their backgrounds. While $4.07 \%$ of our participants have a doctoral degree and $8.94 \%$ have a professional degree, $34.96 \%$ have a master's and $38.21 \%$ have a bachelor's degree. Thus, $13.82 \%$ of our participants have less than a bachelor's degree. Concerning education, there is no statistically significant difference between female and male participants. However, our female participants work less often for listed companies compared to our male participants. Consequently, our male participants work for employers with higher revenues and more employees compared to our female participants (untabulated). In addition, for our female participants, financial targets account for a higher portion of their incentive programs, while sustainability goals account for a smaller portion of their incentive programs compared to our male participants. Also, our female participants have held their current professional roles longer than our male participants. However, there are no statistically significant differences between our low and high shareholder pressure conditions in terms of participants' gender, education, salary, and incentive program and in terms of employer characteristics such as revenue and number of employees (untabulated).

Table 1 and Fig. 2a-c show relevant participant and firm characteristics. On average, our participants have been with their respective companies for approximately nine years and $76 \%$ of our participants earn an annual fixed salary above $\$ 100,000$. Additionally, $71 \%$ of our participants' employers generate more than $\$ 11$ million per year in revenues and have more than 100 employees. Therefore, we are confident that our participants' decisions can be generalized and represent executive decisionmaking adequately.

\subsection{Design and Procedure}

Participants assume the role of an executive belonging to the management board of fictitious Firm Y. Participants view the background information and financial information of Firm Y, which is a hypothetical global manufacturer based in the United States. The financial information is adapted from a real-world example and comprises income statements for the years 2018 and 2019. Our experiment observes participants' allocation of money to three attributes of an investment-markup in shortterm-profit/upcoming year dividend per share, improvement in ecological standards and/or improvement in social standards. We test our hypotheses using an experimental design. We manipulate shareholder pressure by varying Firm Y's relative financial performance to its peers as well as resulting shareholder satisfaction with Firm Y's performance (high vs. low shareholder pressure; similar to Espahbodi et al. 2019). In the low shareholder pressure condition, Firm Y's sales and earnings increase by $10 \%$ from 2018 to 2019 , while those of industry peers only grow by $2 \%$ on average, and shareholders are satisfied with Firm Y's performance. In the high shareholder pressure condition, Firm Y's sales and earnings decrease by $10 \%$ from 2018 to 2019, while those of industry peers only experience an average decrease of $2 \%$, and Firm Y's shareholders are unsatisfied with Firm Y's performance. Nev- 
ertheless, in both conditions, Firm $\mathrm{Y}$ is profitable and generates over $\$ 4$ billion in revenues, with a return on sales of approximately $4.7 \% .^{7}$

Our study begins by asking participants to assume the role of an executive on Firm Y's management board. Next, participants view background information on Firm Y and either the low or high shareholder pressure income statement. Information is adapted from a real manufacturing firm and comprises a comparative income statement for the years 2018 and 2019. Additionally, participants learn that they, in their role as executives, are personally invested in Firm Y and participate in its dividend payout. We then explain that the variable compensation of participants depends on the upcoming dividend per share of Firm Y. Subsequently, participants learn that Firm Y plans to invest $\$ 100$ million in a new production facility to increase growth and profitability. We also explain that if Firm Y chooses to maximize profits and the upcoming dividend per share, participants will earn $\$ 3$ as variable pay $(10 \times$ their allocation to dividend per share), but social and ecological standards at the new production facility will then not exceed minimum legal requirements. However, Firm Y can also improve social (e.g., working conditions and the benefit to the local community) and/or ecological standards (e.g., greenhouse gas emissions and waste reduction), which will reduce the markup in the upcoming dividend per share. Next, we explain that the management board of Firm Y leaves it up to the participant acting as a member of management to decide if Firm $\mathrm{Y}$ focuses on maximizing the upcoming dividend per share or improves social and/or ecological standards at the new production facility. Using sliders, participants allocate 30 cents of the earnings per share to the three attributes of the project. To not only incentivize participants with their personal compensation, which is linked to the upcoming dividend per share of Firm Y, we also explain to them that we donate money allocated to improving ecological and social standards to respective U.S. charities after our experiment is finished. ${ }^{8}$ After deciding on the allocation of money to the specific features of the project, participants answer post-experimental questions. To measure participants' risk propensity, we employ the 8-item gambling and investing risk-taking propensity subscale of the domain-specific risk-taking (DOSPERT) scale (Markiewicz and Weber 2013; Weber et al. 2002), which captures the specific risk propensity of individuals in the investment decision-making domain. The DOSPERT scale is a proven and reliable scale used for measuring risk propensity in specific domains (Breuer et al. 2016; Wu and Cheung 2014) and Highhouse et al. (2017) highlight the scale's usefulness for predicting real-world outcomes. A Cronbach's alpha of 0.643 indicates acceptable internal validity. We use the 17-item Environmental Attitudes Scale (EAS) (Ebenbach et al. 1998; Kortenkamp and Moore 2001) to measure participants' attitude towards sustainability. A Cronbach's alpha of 0.873 indicates strong internal validity. In addition, the EAS has a high correlation with

\footnotetext{
7 In the base year of 2017, Firm Y generates \$4,494 million in annual revenues and \$211 million in profits. In our low shareholder pressure condition, Firm Y generates \$4,943 million in revenues and earns \$231 million in profits in 2018, while in our high shareholder pressure condition, Firm Y generates $\$ 4,045$ million in revenues and earns $\$ 190$ million in 2018.

8 Following participants' decisions, we donated a total of $\$ 115.36$ to The Nature Conservancy and \$111.00 to Scholarship America.
} 
other environmental attitude scales (e.g. Dunlap and Van Liere 1978). Therefore, we are convinced that we adequately capture participants' attitude towards sustainability. To measure participants' empathy, we use two 7-item empathy subscales developed by Davis (1980), the perspective-taking scale and the empathic-concern scale, which assess participants' ability to "adopt the perspective [...] of other people" and the "ability to experience feelings of [...] compassion and concern for others undergoing negative experiences" (Dietz and Kleinlogel 2014). A Cronbach's alpha of 0.643 indicates acceptable internal validity. We also include further post-experimental questions capturing participants' real-life salary structure. Specifically, we ask participants what proportion of their salary is variable and what percentage of their total compensation is attributable to the achievement of financial goals, sustainability goals, personal development goals, or other goals. We capture participants' real-life incentive programs because we expect that participants' decisions in our experiment are influenced by how participants are incentivized in their everyday business environment. A more detailed description of our experimental material can be found in the Appendix.

\subsection{Dependent and Explanatory Variables}

We ask participants to allocate 30 cents to either the markup in short-term profits, i.e., the markup in the upcoming year dividend per share, the improvement in social standards and/or the improvement in ecological standards. The distribution must add up to 30 cents, but any allocation to the three attributes is possible. Our main dependent variable, hereafter labeled CSR investment, is the sum of participants' allocation of money to improve social standards and ecological standards, as both attributes are considered beneficial for society, are subsumed under the term CSR and represent a voluntary investment of Firm Y (Carroll 1999). As shown in Fig. 3, par-

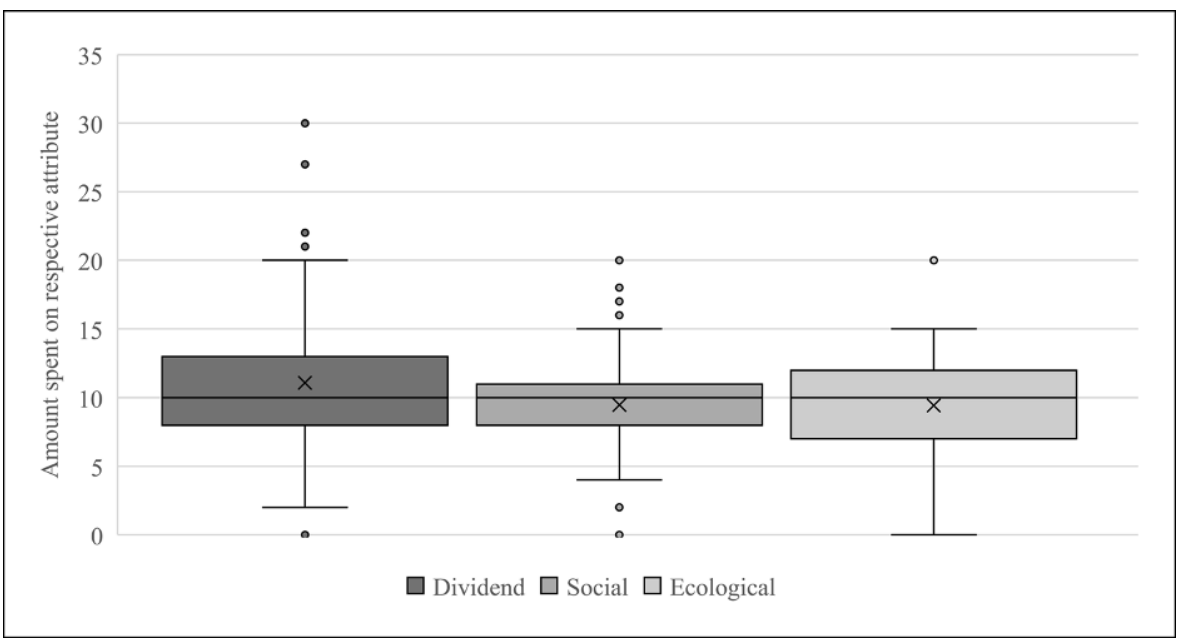

Fig. 3 Distribution of participants' allocation to dividend (short-term profit), social standards, and ecological standards in our experiment 
ticipants' allocation to the improvement of social and ecological standards is rather similar. Additionally, we focus on executives' general investment behavior regarding investments in CSR and do not differentiate between the ecological and social dimensions when deriving our hypotheses. Therefore, from a theoretical standpoint, it is also consistent to sum up participants' investment in improving ecological and social standards.

In our experiment, a participant's decision only affects dividends per share for the upcoming year, as we do not address years beyond that point. However, we explain to participants that improving social and ecological standards is generally beneficial for workers of Firm Y and the local community and helps in protecting the environment. Definitions of CSR usually emphasize firms' contributions to society and a cleaner environment and underline the inherent long-term relationship between business and society (Ackerman 1975; Bowen 2013). Generally, CSR activities focus on long-term success rather than short-term profit (Hang et al. 2019; Porter and Miles 2013). Both the improvement in working conditions and the protection of the environment are sustainable actions that can be seen as prudent and responsible management (Carroll 1999; Dickson and Chang 2015). Therefore, with our CSR investment variable, we capture participants' long-term orientation and their focus on the improvement of sustainable business practices and future earnings, while the counterpart, participants' investment in the profitability and dividend per share of Firm $\mathrm{Y}$ in the upcoming year, displays their short-term profit orientation.

We capture our first explanatory variable "gender" by asking participants to indicate their gender during our post-experimental questions. We also measure participants' incentive programs and capture what percentage of participants' salary is attributable to financial goals. ${ }^{9}$ Thus, our second explanatory variable "financial goals" can range from 0 to 100 . The third explanatory variable "shareholder pressure" captures participants' random distribution to the low or high shareholder pressure condition.

\section{Results}

\subsection{Manipulation Checks}

To assess the effectiveness of our shareholder pressure manipulation, we ask participants to agree (disagree) with the following statement: "The case description said that Firm Y's shareholders were very satisfied with Firm Y's performance". Participants answered on a five-point scale ranging from $1=$ "strongly disagree" to $5=$ "strongly agree". Participants in the low shareholder pressure condition perceived a significantly lower shareholder pressure than participants in the high shareholder

\footnotetext{
9 We asked participants to indicate what portion of their total annual salary is attributable to achieving financial goals, sustainability goals, personal development goals, or other goals.
} 
pressure condition (means 4.178 and 3.164 , respectively; $\mathrm{t}_{123}=4.50, p<0.001$, twotailed). ${ }^{10}$ Thus, we conclude that our manipulation works.

\subsection{Analysis and Test of Hypotheses}

\subsubsection{Regression Results}

To test our hypotheses, we use a regression model with shareholder pressure as our manipulated variable, participants' gender, financial goals, and the interaction term of gender and financial goals. We include the interaction term of gender and financial goals, as we have an uneven distribution of financial goals over shareholder pressure and gender (see Table 2) and the effect of financial goals on CSR investment is stronger for female executives (see Fig. 4).

In Hypothesis 1a, we predict that female executives are more willing to sacrifice short-term financial return to improve social/ecological standards when making investment decisions than male executives. As indicated in Table 3, we find a significant and positive association between gender and CSR investment $(3.394 ; p=0.047$, one-tailed). ${ }^{11}$ Thus, we can provide some evidence that female executives are more oriented towards social and sustainable practices per se. This finding is in line with many archival studies that find a positive association between board gender diversity and CSR performance. However, the structural equation model described later on will add nuances to this conclusion with interesting further implications.

In Hypothesis 2, we predict that the orientation towards financial goals in executives' incentive programs negatively affects their CSR investment. Table 3 shows

Table 2 Mean distribution of financial goals (\% of salary attributable to achieving financial goals) over gender and shareholder pressure conditions

\begin{tabular}{lllll}
\hline \multirow{2}{*}{ Shareholder Pressure } & & \multicolumn{2}{l}{ Gender } & Total \\
\cline { 3 - 5 } Low & Mean & 34.53 & 51.39 & 39.95 \\
& Std. Dev. & 16.73 & 28.84 & 22.55 \\
\multirow{3}{*}{ High } & $N$ & 38 & 18 & 56 \\
& Mean & 37.62 & 42.72 & 39.522 \\
& Std. Dev. & 19.433 & 27.30 & 22.62 \\
Total & $N$ & 42 & 25 & 67 \\
& Mean & 36.15 & 46.35 & 39.72 \\
& Std. Dev. & 18.15 & 27.95 & 22.50 \\
& $N$ & 80 & 43 & 123 \\
\hline
\end{tabular}

\footnotetext{
10 The result for our other statement "The case description said that Firm Y's financial performance was very good" is similar (means 4.25 and 3.373 respectively; $\mathrm{t}_{123}=4.319, p<0.001$, two-tailed) and also shows that our manipulation worked.

11 We present our results with a one-tailed $p$-value when we have formulated a directed hypothesis, and with the two-tailed $p$-value if that is not the case. In our OLS regression, the coefficient of gender is 3.39. Thus, ceteris paribus, female executives spent 3.39 Cents more on CSR than male executives in our experiment. As male executives spent on average 19.04 Cents on CSR, this means that female executives spent approximately $18 \%$ more on CSR than male executives.
} 


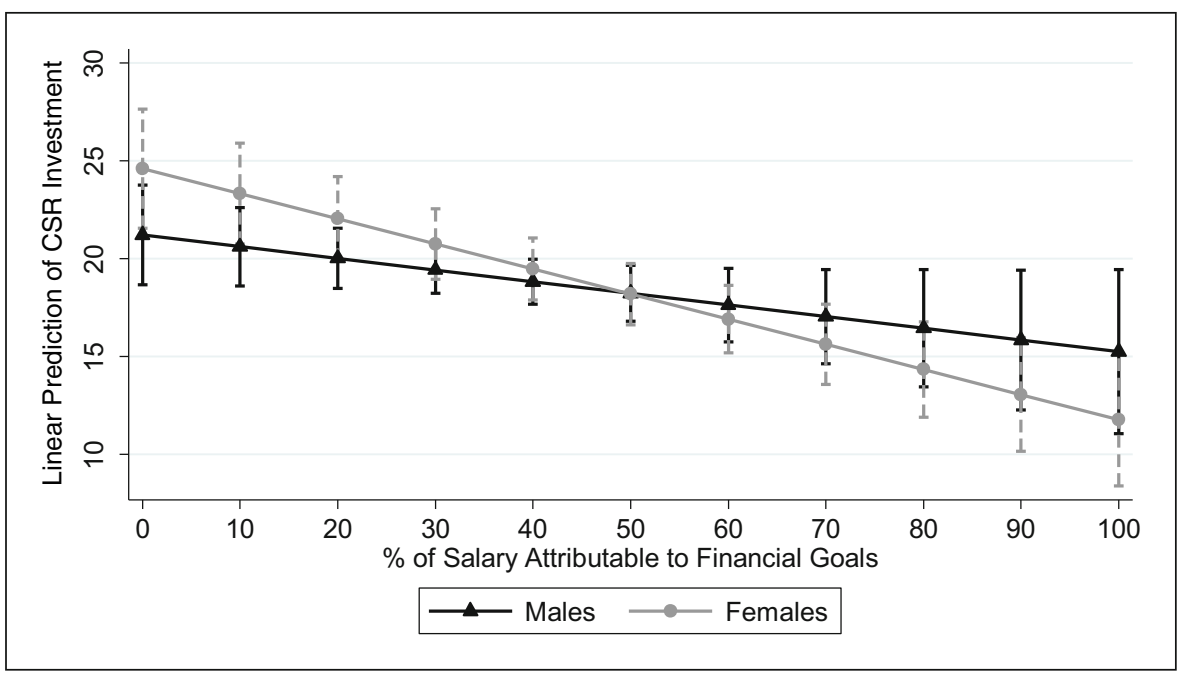

Fig. 4 Linear prediction of CSR investment and the portion of financial goals in participants' incentive program for female and male executives

our financial goals variable, which indicates what percentage of participants' salary is attributable to financial goals, is statistically significant and negatively associated with CSR investment $(-0.060 ; p=0.032$, one-tailed). Also, Fig. 4 emphasizes that, for both genders, executives' CSR investment decreases with increasing relevance of financial goals in executives' incentive programs. Therefore, we find evidence that greater relevance of financial goals achievement in executives' incentive programs reduces their willingness to invest in CSR. Consequently, we find support for Hypothesis $2 .{ }^{12}$

In Hypothesis 3, we predict that shareholder pressure affects executives' willingness to sacrifice financial return to improve social/ecological standards when making investment decisions. Table 3 shows that our binary shareholder pressure variable, which indicates whether participants were assigned to the low (value of variable $=0$ ) or high (value of variable $=1$ ) shareholder pressure condition, is not statistically significant $(0.236 ; p=0.401$, one-tailed).

Thus, we do not find support for Hypothesis 3 . Therefore, we show that, in our case, a firm's relative performance to the industry average and resulting shareholder (dis)satisfaction do not affect executives' CSR decision-making. This finding is consistent with Nelling and Webb (2009) who do not find a direct causal link between a firm's performance and aspects of CSR related to the community or environment. Our results continue to hold when we control for specific participantor employer characteristics that significantly differ between our male and female participants, such as tenure in their current corporate role, revenue or number of

\footnotetext{
12 Our results for executives' incentive programs continue to hold if we exclude participants with unconventional incentive programs, like programs with a ratio of sustainability goals above $30 \%$ or a ratio of financial goals below $50 \%$.
} 
Table 3 Regression-Model of CSR Investment

\begin{tabular}{llll}
\hline Variables & \multicolumn{2}{l}{ CSR Investment } & \\
& $\beta$ & $\begin{array}{l}\text { Two-tailed } \\
p \text {-value }\end{array}$ & $\begin{array}{l}\text { One-tailed } \\
p \text {-value }\end{array}$ \\
\hline Constant & $21.069^{* * *}$ & $<0.001$ & $<0.001$ \\
Gender & $3.394^{* *}$ & 0.094 & 0.047 \\
Financial Goals & $-0.060^{* *}$ & 0.064 & 0.032 \\
Gender $\times$ Financial Goals & -0.069 & 0.111 & 0.056 \\
Shareholder Pressure & 0.236 & 0.801 & 0.401 \\
$N$ & 123 & & \\
Adj. $\mathrm{R}^{2}$ & 0.1436 & & \\
\hline
\end{tabular}

We report the one-tailed $p$-value where we have formulated a directed hypothesis, and the two-tailed $p$ value if that is not the case. Gender is equal to 1 for female participants. Shareholder pressure is equal to 1 for the high shareholder pressure condition

$* p<0.10 ; * * p<0.05 ; * * * p<0.01$

employees of the employer or the variable that indicates if participants' employer is a listed firm.

\subsubsection{Structural Equation Model}

Our main analysis provides some evidence for a positive association between participants' gender and CSR investment. However, prior studies show that executives' personal characteristics and beliefs affect their investments in CSR activities (Agle et al. 1999; Chin et al. 2013; Hafenbrädl and Waeger 2017). Gender as a variable captures different character traits, which in turn might influence CSR investment. Based on the research focusing on gender differences, including archival research analyzing the effect of gender diversity in governance and management boards on CSR performance, we identify three possible character traits that might drive CSR investment: risk propensity, attitude towards sustainability, and empathy.

Fig. 5 shows the design and corresponding results of our maximum likelihood structural equation model. The traditional Chi-square test indicates a good fit of our model $\left(\chi^{2}=4.491 ; p=0.611\right)$, which is supported by the Comparative Fit Index (1.000; above the generally accepted minimum of 0.95; Byrne 2013). Also, the Root Mean Square Error of Approximation (0.000; below the 0.05 rule of thumb) indicates a good fit (MacCallum et al. 1996). ${ }^{13}$

\footnotetext{
${ }_{13}$ With sample size requirements being an important question in studies using SEM (Westland 2010), it is necessary to acknowledge that we had to satisfice with a quite small sample of 123 observations, as recruiting executives for experimental research is rather costly. Yet, we generally meet existing rules of thumb for minimum sample sizes in SEM (e.g., 10 observations per indicator, aggregating to a minimum sample size of 70 in our case) (e.g., Nunnally 1967; Kahai and Cooper 2003; Wolf et al. 2013). Furthermore, other studies using SEM have worked with sample sizes much smaller than the sample size in this study (van Raaij and Schepers 2008; So and Bolloju 2005; Venkatesh and Davis 2000; Yoo and Alavi 2001; Ratzinger-Sakel and Theis 2019), and sample sizes as small as 50 can produce reliable results under certain conditions (Hoyle and Gottfredson 2015). Especially when the estimation converges-as in the present case-concerns rather shift to the evaluation of fit (Hoyle and Gottfredson 2015; Ratzinger-Sakel and Theis 2019).
} 


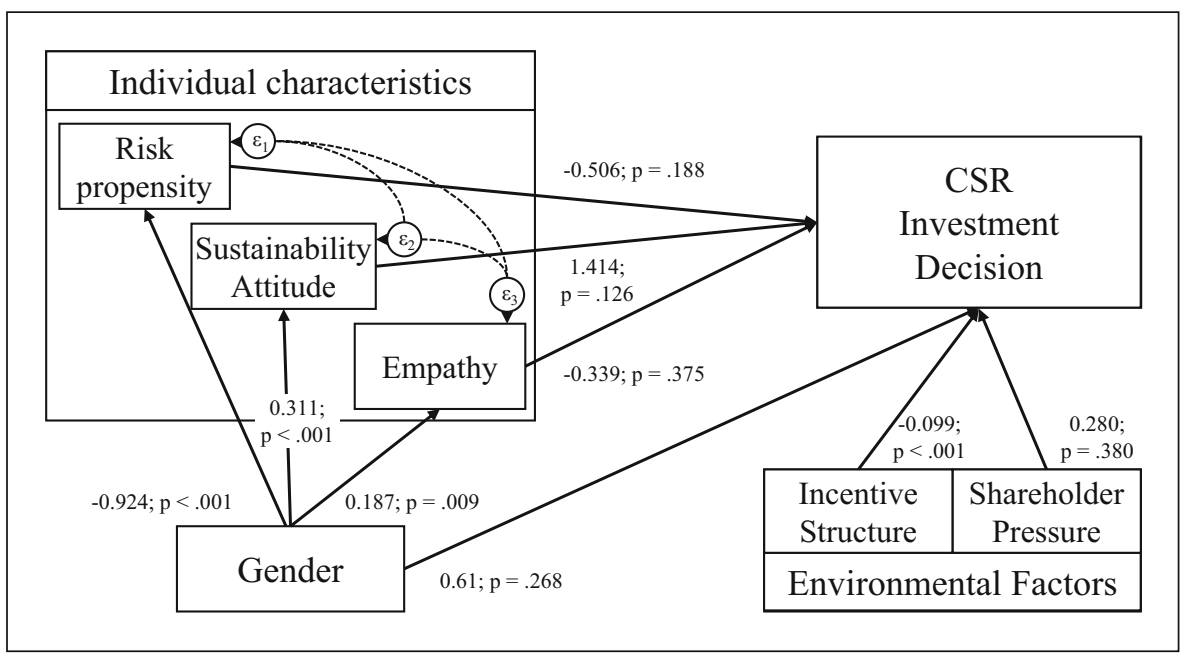

Fig. 5 Structural equation model (total effects) of gender specific character traits, external factors and CSR investment. $P$-values based on one-tailed tests

In Hypothesis 1a, we predict that female executives are more willing to sacrifice short-term financial return to improve social/ecological standards when making investment decisions than male executives. We find only minimal support for Hypothesis 1a in our regression. Our SEM, as displayed in Fig. 5, shows that gender is significantly associated with the character traits risk propensity, attitude towards sustainability, and empathy. According to our SEM, female participants are risk-averse $(-0.924 ; p<0.001)$, have a stronger attitude towards sustainability $(0.311 ; p<0.001)$ and are more empathetic $(0.187 ; p=0.009)$ compared to male participants. However, we do not find that these character traits have a statistically significant association with CSR investment $(-0.506 ; p=0.188,1.414 ; p=0.126$ and $-0.339 ; p=0.375$ respectively), and hence do not find evidence for a mediating effect as proposed in Hypotheses 1b1-1b3. This is surprising as studies on gender differences often use these character traits as an explanation for differences between females and males (e.g. Cabeza-García et al. 2018; Francis et al. 2015; Francoeur et al. 2019; Glass and Cook 2018). In our context, however, it seems that participants' incentive program overrides the relation between their character traits and CSR investment, as the ratio of financial goals within participants' incentive programs is strongly associated with participants' CSR investment $(-0.099 ; p<0.001)$, which further supports Hypothesis $2 .{ }^{14}$ This finding is highly interesting as it adds further insights to findings of prior studies investigating the association between board gender diversity and

\footnotetext{
14 Prior to conducting our experiment with participants from a private survey company, we conducted a previous version of our experiment with participants from Amazon's Mechanical Turk (AMT) platform. The participants from AMT were used to gather some initial evidence and displayed a sample of the general public rather than executives. We found that risk propensity and attitude towards sustainability affect AMT participants' CSR investment. As risk propensity and attitude towards sustainability do not affect executives' CSR investment, we conclude that executives' real-world incentive programs may override the impact of personal character traits on their CSR investment decisions.
} 
CSR performance. While our results confirm gender differences regarding character traits which are seen as important drivers of CSR investments, our findings suggest that it is essential to control for executives' incentive program to arrive at valid conclusions. ${ }^{15}$ In line with the results from our regression, we do not find a significant effect of our shareholder pressure variable on executives' CSR investment $(0.280 ; p=0.759)$ in the SEM.

In our SEM, we also capture a direct effect of gender on CSR investment, which corresponds to our Hypothesis 1a. As displayed in Fig. 5, this effect is not significant $(0.61 ; p=0.536)$, as some part of a potential direct effect of gender on CSR investment is likely captured by the three distinguished character traits we included in our SEM. Thus, it is not surprising that the statistically weak significant effect of gender on CSR investment vanishes in our SEM, as other gender-dependent character traits are included and may mediate a direct effect to some degree.

\subsubsection{Additional Exploratory Analysis}

Bryant et al. (2020) show that external pressure (in form of direct regulatory and stakeholder pressure on firms that primarily contribute to greenhouse gas emissions) influences how firms engage in environmental actions to reduce climate change. However, they also find that this relationship is positively moderated by a firm's attitude towards risk. We use these insights as the departure point for additionally investigating the following Research Question 1 (RQ1):

Research Question 1 Does shareholder pressure moderate the effect of risk propensity on the investment decision to sacrifice short-term financial return to improve social/ecological standards?

For this rather exploratory analysis, we expand our SEM by also including the interaction between risk propensity and shareholder pressure. ${ }^{16}$ We find that our risk propensity variable then has a negative and marginally significant association with CSR investment $(-1.41 ; p=0.056$, two tailed, untabulated), just as our shareholder pressure variable $(-5.34 ; p=0.093$, two tailed, untabulated). In contrast, the interaction term of risk propensity and shareholder pressure is positively associated with CSR investment and marginally significant (1.75; $p=0.065$, two tailed, untabulated). Fig. 6 displays the linear predictions of participants' spending for our low and high shareholder pressure conditions and the risk propensity scale. In our high shareholder pressure condition, in which Firm Y's performance is below the industry

\footnotetext{
15 The scales we use to capture the three character traits risk propensity, sustainability attitude, and empathy (see Sect. 3.2 for details) constitute self-report measures, i.e. measures relying on individuals' own reports of their attitudes and beliefs. Self-report measures have several fundamental limitations (e.g., Morgado et al. 2017). Measurement quality may for example be impaired if individuals hold implicit beliefs that to not translate to explicit responses to the stated questions (Axt 2018). It is, therefore, possible that the lack of evidence for a mediating effect of the three character traits is due to limitations inherent in the underlying scales.

16 Interaction terms for either empathy or attitude towards sustainability and shareholder pressure do not produce significant and meaningful results and are thus not included in our exploratory analysis.
} 
average and shareholders express that they are unsatisfied with the performance, participants with a higher risk propensity invest more in CSR.

While the specific type of pressure analyzed in our experiment differs from Bryant et al. (2020), our findings are still in line with that study. Bryant et al. (2020) find that firms with a high risk propensity are more likely to engage in beyondcompliance environmental actions under high external pressure. They conclude that those firms are more willing to hedge risks arising from climate change, as they view climate change risk differently than financial risk. In our high shareholder pressure condition, shareholders are unsatisfied as Firm Y's financial performance is below the industry average. Consequently, risk-averse participants invest more into shortterm profitability. In contrast, participants with a high risk propensity invest more into CSR in our experiment, so that the social and ecological standards exceed minimum legal requirements.

In our low shareholder pressure condition, in which Firm Y performs above the industry average and shareholders are satisfied, the response pattern is opposite. Participants with a high risk-propensity invest less in CSR (more in short termprofit) and increase their own profit. As indicated by the slope of the two functions in Fig. 6, the difference in CSR investment between high and low risk propensity participants is higher for the low shareholder pressure condition. In this condition, Firm Y performs above the industry average and shareholders are satisfied and thus, managers should have greater discretion in allocating resources than in the high shareholder pressure condition (Arora and Dharwadkar 2011). Some studies find that risk propensity is connected to greed in specific settings (Li et al. 2019), which corroborates our finding that, in our low shareholder pressure condition, participants with a high risk propensity invest more in short term-profit and increase their own profit. This is in line with Sajko et al. (2021) who find that greedy CEOs invest less in CSR. Interestingly, Bryant et al. (2020) also show that firms that are not subject to regulatory pressure are less likely to engage in beyond-

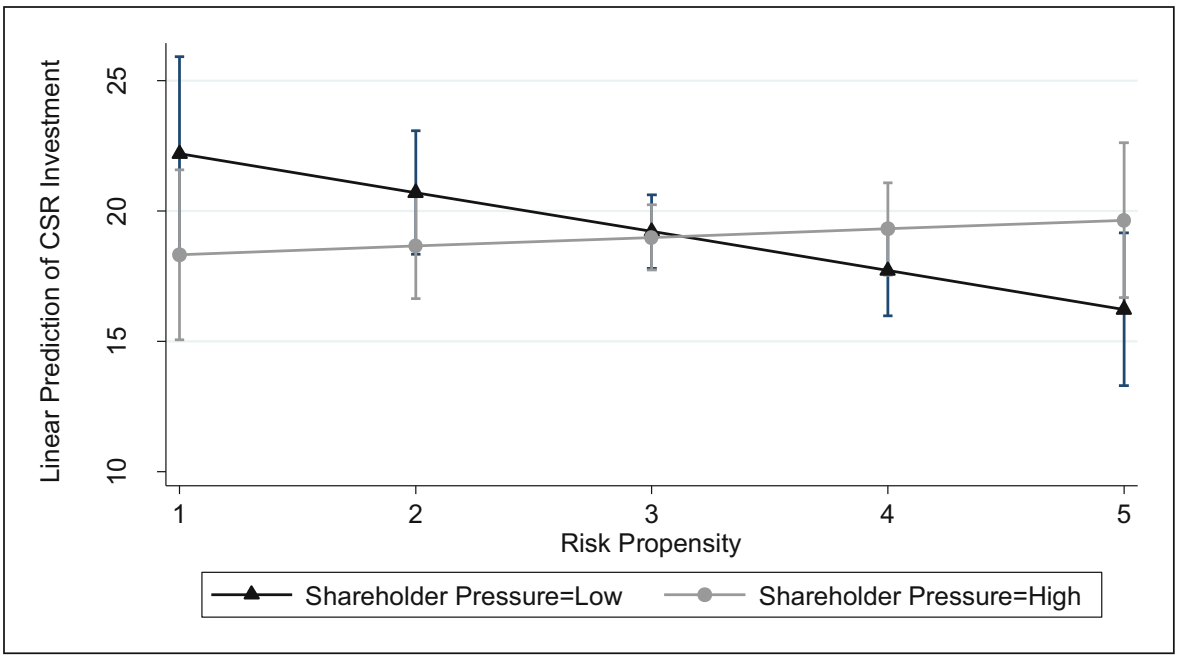

Fig. 6 Linear prediction of CSR investment and risk propensity for high and low shareholder pressure 
compliance environmental actions if they have a high risk propensity. Again, this matches our findings and underlines that executives with a high risk propensity cut CSR investments to increase their own profits when having discretion in allocating resources.

\section{Conclusion}

The public demand for sustainable corporate behavior is omnipresent and firms intensively invest in CSR activities (Johnson et al. 2020b; Moser and Martin 2012). Archival research linking female board and management representation with CSR performance generally finds positive associations (e.g. Francoeur et al. 2019; Glass and Cook 2018; Hafsi and Turgut 2013; Harjoto et al. 2015) but does not provide conclusive evidence for why gender impacts CSR performance.

We experimentally examine executives' consideration of sustainable and social attributes in investment decisions. In line with social theory (Eagly 1987; Eagly and Wood 1991) and based on the positive evidence of most archival studies on the association between female board representation and CSR performance, we predict that female executives are more willing to sacrifice financial return to improve social/ ecological standards when making investment decisions than male executives (H1a). We find weak statistical support for this prediction.

However, we observe participants' incentive programs and, consistent with our prediction, find that the relevance of achieving financial goals in participants' realworld incentive programs significantly affects their CSR investment (H2).

Additionally, we manipulate shareholder pressure and examine how executives' CSR investments differ between a high and low shareholder pressure condition (H3). We do not find significant evidence for an effect of shareholder pressure on executives' CSR investment.

We also employ a structural equation model and find that gender is significantly associated with the character traits risk propensity, attitude towards sustainability, and empathy. However, we do not find that these character traits have a statistically significant association with the CSR investment (H1b1-1b3). This is surprising as studies on gender differences often use these character traits as an explanation for differences between females and males (e.g. Cabeza-García et al. 2018; Francis et al. 2015; Francoeur et al. 2019; Glass and Cook 2018). However, in our additional exploratory analysis in relation to RQ1, we find that risk propensity in connection with our shareholder pressure manipulation affects executives' CSR decision-making.

Our study makes important contributions to the CSR literature and the literature on executives' decision-making. To the best of our knowledge, our study is the first to explicitly, experimentally analyze gender differences in executives' CSR investment behavior. We expand the literature on the impact of female executives on corporate decision-making (e.g. Francis et al. 2015; Huang and Kisgen 2013; Levi et al. 2008; Mohan and Chen 2004) and on the association between female executives and CSR performance (e.g., Francoeur et al. 2019; Glass and Cook 2018; Harjoto et al. 2015). With our experimental analysis, we can generally confirm a positive impact of female executives on firms' CSR performance. However, although we do find that the 
character traits often used in archival are gender-dependent, we do not find evidence that these character traits affect executives' CSR decision-making. Additionally, in line with Fabrizi et al. (2014) and Flammer et al. (2019), we find that executives' real-world incentive programs play a key role in explaining executives' CSR decision-making. Thus, we contribute to a growing stream of literature on CSR decisionmaking (Wang et al. 2016). By outlining that it is essential to control for executives' real-world incentive programs to derive valid inferences when examining executives' decision-making. Finally, our study offers important practical implications. As we find that executives' incentive program strongly affects their CSR decision-making, we encourage firms that want to increase their CSR activities to consider redesigning their executives' incentive programs. By emphasizing the positive impact of female executives on firms' CSR performance, our study also offers implications for policymakers and for firms themselves, which will continue to face public and investor pressure to expand their social and ecological activities and, therefore, must adapt their corporate decision-making to address all stakeholder concerns.

While our study offers important contributions, it also has its limitations and provides avenues for future research. First, we manipulate shareholder pressure with the relative performance of a company to its peer group as well as shareholder satisfaction and do not find an impact on executives' decision-making. Retrospectively, our manipulation might have been insufficiently strong to trigger different decisions of executives. Second, with sample size requirements being an important question in studies using SEM, we acknowledge that we had to satisfice with a quite small sample of 123 observations, as recruiting executives for experimental research is rather costly. In addition, the small sample size may reduce the generalizability of our results. Third, we are naturally not able to manipulate participants' real-life incentive programs. Thus, we cannot completely rule out that a portion of our results with respect to participants' incentive programs can be attributed to more altruistic participants choosing jobs with lower proportions of financial performance targets (Buurman et al. 2012).

Future research should further examine if shareholder pressure, induced by a firm's financial performance, affects executives' CSR decision-making. Also, there are other reasons why shareholders might be dissatisfied with a company's activities or performance, which might affect executives' behavior differently. Consequently, future research could explore how executives react to different types of shareholder pressure and how this affects their investment decisions. Furthermore, although we do not find significant effects for our three character traits on CSR investment, we encourage future experimental research to further examine specific character traits and their effects on executives' decision-making, in terms of gender differences, CSR, and in other contexts. 


\section{Appendix}

\section{Detailed Description of our Experiment}

Our experiment was conducted online using the Unipark software (https://www. unipark.com/en/). This allows participants to complete our experiment on their own device of their choice. First, participants read a consent form explaining their compensation, confidentially rights, and other generic information. After that, participants answer several screening questions. The first screening question asks if participants work for a for-profit organization. Only participants that answer "yes", continue with the survey, while the answer "no" leads to an exit screen that tells participants that they are not eligible for the study. Our next screening question asks to which industry the organization participants work for belongs. The answers "Consumer Nondurables", "Consumer Durables", "Manufacturing", "Energy", "Chemicals and Allied Products", "Business Equipment", "Telephone and Television Transmission", "Utilities", "Wholesale, Retail, Laundries, Repair Shops", "Healthcare, Medical Equipment, and Drugs", and "Other—not mentioned" are accepted, while participants that select "Finance" automatically exit the survey via the exit screen. The third screening question asks participants in which domain they primarily worked. The answers "Governance", "Strategy", "Finance", "Accounting", and "Operations/Production" are accepted, while participants answering "Marketing", "Sales", "Human Resources", "Research and Development" or "Other domain

Background Information

The purpose of this study is to examine how executives make judgments and decisions. Your participation should take less than 15 minutes.

For the success of this research, II IS CRITICAL THAT YOU PAY ATTENTION to the information presented to you.

In this study. please assume that you are an executive serving on Firm Y's management board. The management board is responsible for the overall strategy of Firm $\mathrm{Y}$ and decides on the realization of investment options. Those options define the future success of Firm $\mathrm{Y}$ and range from investments in new production facilities to investments in staff development. Firm $Y$ is a mature, global manufacturer and distributor based in the United States. Below is an excerpt from Firm Y's income statement for the past two years 2018 and 2019 . The increase of approximately $10 \%$ in Firm Y's revenue, net income and earnings per share (EPS) from 2018 to 2019 is significantly higher than the average growth of $2 \%$ between 2018 and 2019 among firms in Firm Y's industry. At the last annual general meeting. shareholders generally expressed that they are very satisfied with Firm Y's performance.

Furthermore, please assume that you own shares in Firm $Y$. That means that you participate in the share price development of Firm $Y$ and can expect a regular dividend payout, which is a portion of the earnings per share (EPS). In the last years, Firm $Y$ paid out $50 \%$ of the earnings per share (EPS) as the dividend per share.

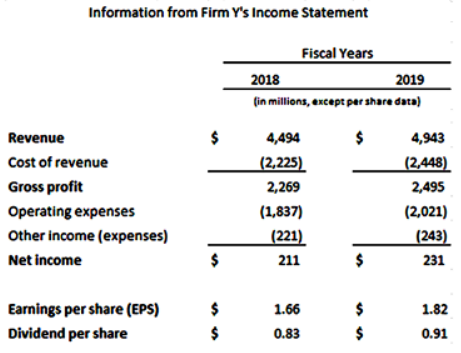

In addition to your flat compensation for participating in this study, you can earn a variable compensation of up to $\$ 3.00$. Your variable compensation depends on Firm Y's projected dividend per share for 2020. which depends on the decisions that you make in the following. The variable compensation of up to $\$ 3.00$ will be paid out to you in the form of an Amazon voucher. At the end of this survey, we provide you with a URL to a website where you can download the voucher after May 31st.

Fig. 7 Background information low shareholder pressure condition 
Background Information

The purpose of this study is to examine how executives make judgments and decisions. Your participation should take less than 15 minutes.

For the success of this research, IT IS CRITICAL THAT YOU PAY ATTENTION to the information presented to you.

In this study. please assume that you are an executive serving on Firm Y's management board. The management board is responsible for the overall strategy of Firm $\mathrm{Y}$ and decides on the realization of investment options. Those options define the future success of Firm $\mathrm{Y}$ and range from investments in new production facilities to investments in staff development. Firm $Y$ is a mature, global manufacturer and distributor based in the United States. Below is an excerpt from Firm Y's income statement for the past two years 2018 and 2019. The decrease of approximately 10\% in Firm Y's revenue, net income and earnings per share (EPS) from 2018 to 2019 is significantly higher than the average negative growth of $2 \%$ between 2018 and 2019 among firms in Firm Y's industry. At the last annual general meeting. shareholders generally expressed that they are very unsatisfied with Firm Y's performance.

Furthermore, please assume that you own shares in Firm $Y$. That means that you participate in the share price development of Firm $Y$ and can expect a regular dividend payout, which is a portion of the earnings per share (EPS). In the last years, Firm $Y$ paid out $50 \%$ of the earnings per share (EPS) as the dividend per share.

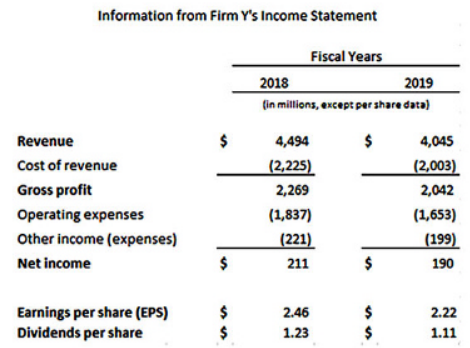

In addition to your flat compensation for participating in this study, you can earn a variable compensation of up to $\$ 3.00$. Your variable compensation depends on Firm Y's projected dividend per share for 2020. which depends on the decisions that you make in the following. The variable compensation of up to $\$ 3.00$ will be paid out to you in the form of an Amazon voucher. At the end of this survey, we provide you with a URL to a website where you can download the voucher after May 31st.

Fig. 8 Background information high shareholder pressure condition

not mentioned" automatically exit the experiment. The next screening question asks participants to indicate what role they have in their organization. The answers "I am a member of the board of directors of my organization", "I am a member of the executive board of my organization", and "I am a member of the senior management of my organization" are accepted. Participants that answer "I am a member of midor lower-level management of my organization" are additionally asked how frequently they are involved in significant investment decisions. Of these participants, only the ones answering "very often", "often", or "sometimes" pass the screening. Participants that select "never" or "rarely" exit, which also applies to participants who select "I am not a member of management of my organization" in the previous question.

After the screening questions, participants were randomly assigned to either our low or high shareholder pressure conditions, which are presented in Figs. 7 and 8.

After reading the background information, participants are introduced to the investment decision, which is presented below (Fig. 9).

After the investment decision, participants answer post-experimental questions. The first two questions assess participants' comprehension of the case by asking them to indicate their agreement with the following statements on a scale from 1-strongly disagree to 5-strongly agree: "The case description said that Firm Y's financial performance was very good" and "The case description said that Firm Y's shareholders were very satisfied with Firm Y's performance”. After that, the 8-item gambling and investing risk-taking propensity subscale of the domain-specific risk- 
Additional Information

To increase growth and profitability in the future. Firm $Y$ plans to invest $\$ 100$ million in a new production facility for a new product. If Firm $Y$ chooses to invest the $\$ 100$ million in a manner that maximizes Firm Y's short-term profits, the projected dividend per share for 2020 increases from $\$ 1.00$ by $\$ 0.30$ to the maximum of $\$ 1.30$. This can only be achieved if the social and ecological standards at the new production facility do not exceed minimum legal requirements.

However. Firm Y can also choose to improve social and ecological standards at the new production facility so that they exceed minimum legal requirements. Doing so is generally beneficial for workers, the local community and the environment. Furthermore, it is assumed that firms generally benefit from improving social and ecological standards in the long-term. The costs associated with improving social and ecological standards at the new production facility reduce the projected maximum dividend per share of $\$ 1.30$ for 2020 . and hence your compensation.

The other members on Firm Y's management board leave it up to you to decide whether Firm $Y$ focuses on short-term profit-maximization, or improves social and/or ecological standards at the new production facility.

You can indicate your decision by using the sliders below. You can allocate in total 30 Cents (entirely or partially) to increase the dividend per share for 2020, and/or to improve the social and/or ecological standards.

The amount you allocate to increase the dividend per share for 2020 multiplied by 10 will be your variable compensation.

The amounts you allocate to improve the social and/or ecological standards at the new production facility of Firm Y multiplied by 10 will be donated in reality to a US charity with a respective focus.

Hence, if you, for example, allocated $\$ 0.10$ to increase the dividend per share, $\$ 0.10$ to improve the social standards, and $\$ 0.10$ to improve the ecological standards. your variable compensation would equal $\$ 1.00$ and we would in reality donate $\$ 1.00$ to a US charity with a social focus as well as $\$ 1.00$ to a US charity with an ecological focus.

When data collection for this study is over, we will add up the amounts allocated by individual participants to improve the social and/or ecological standards and donate the total amounts. At the end of this survey, we provide you with a URL to a website where you can download the proof for the charitable donations after May 31st.

Please allocate in total 30 Cents (entirely or partially) to increase the dividend per share for 2020, and/or to improve the social and/or ecological standards.

\begin{tabular}{l} 
Additional dividend per share \\
Improvement of ecological \\
standards \\
$\begin{array}{lll}\text { Improvement of social } \\
\text { standards }\end{array}$ \\
\hline Total (needs to equal 30)
\end{tabular}

Fig. 9 Participants' decision about allocation to the three investment attributes

taking (DOSPERT) scale (Markiewicz and Weber 2013; Weber et al. 2002), the 17item Environmental Attitudes Scale (EAS) (Ebenbach et al. 1998; Kortenkamp and Moore 2001), and the two 7-item empathy subscales developed by Davis (1980), the perspective-taking scale and the empathic-concern scale follow. Within these questions, one attention check asks participants to select "strongly disagree" on a five-point scale ranging from "strongly agree" to "strongly disagree". ${ }^{17}$ Participants that do not select "strongly disagree" exit the survey. After the above-mentioned scales, questions about participants' educational background, their age, their salary, their current professional role, and their employer conclude our post-experimental questions. After that, participants see a screen with their completion code and links to their variable pay and our donations to charitable organizations.

Supplementary Information The online version of this article (https://doi.org/10.1007/s41471-02100122-8) contains supplementary material, which is available to authorized users.

17 This attention check was predetermined by the private survey company. 
Acknowledgements We thank the editor and two anonymous reviewers for their thorough comments. We also thank Jillian Alderman (American Accounting Association Annual Meeting Discussant), workshop participants at the University of Hamburg, brown bag participants at the Mercator School of Management at the University of Duisburg-Essen, as well as audience participants at the 2020 American Accounting Association Annual Meeting and the 2021 European Accounting Association Annual Congress for their helpful comments and suggestions.

Funding No funding was received for conducting this study.

Funding Open Access funding enabled and organized by Projekt DEAL.

Open Access This article is licensed under a Creative Commons Attribution 4.0 International License, which permits use, sharing, adaptation, distribution and reproduction in any medium or format, as long as you give appropriate credit to the original author(s) and the source, provide a link to the Creative Commons licence, and indicate if changes were made. The images or other third party material in this article are included in the article's Creative Commons licence, unless indicated otherwise in a credit line to the material. If material is not included in the article's Creative Commons licence and your intended use is not permitted by statutory regulation or exceeds the permitted use, you will need to obtain permission directly from the copyright holder. To view a copy of this licence, visit http://creativecommons.org/licenses/by/4. $0 \%$.

\section{Declarations}

Conflict of interest J. Theis and M. Nipper declare that they have no competing interests.

Ethical standards Our experimental design meets the requirements for using human subjects in experiments at the university where the corresponding author is located and was approved. Consent for publication: Not applicable.

\section{References}

Ackerman, Robert W. 1975. The social challenge to business. Cambridge: Harvard University Press.

Adams, Renée B., and Patricia Funk. 2012. Beyond the glass ceiling: does gender matter? Management Science 58(2):219-235. https://doi.org/10.1287/mnsc.1110.1452.

Adomako, Samuel, Joseph Amankwah-Amoah, Albert Danso, and George O. Dankwah. 2021. CEO sustainability orientation and firm environmental performance: networking and resource contingencies. Business Strategy and the Environment 30(4):2184-2193. https://doi.org/10.1002/bse.2742.

Agle, Bradley R., K. Mitchell Ronald, and Jeffrey A. Sonnenfeld. 1999. Who matters to CEOs? An investigation of stakeholder attributes and salience, corporate performance, and CEO values. Academy of Management Journal 42(5):507-525. https://doi.org/10.5465/256973.

Antón, Miguel, Florian Ederer, Mireia Giné, and Martin C. Schmalz. 2020. Common ownership, competition, and top management incentives. Ross School of Business Paper, 1328. https://doi.org/10.2139/ ssrn.2802332.

Arnold, Vicky, Jean C. Bedard, Jillian R. Phillips, and Steve G. Sutton. 2012. The impact of tagging qualitative financial information on investor decision making: implications for XBRL. International Journal of Accounting Information Systems 13(1):2-20. https://doi.org/10.1016/j.accinf.2011.12.002.

Arora, Punit, and Ravi Dharwadkar. 2011. Corporate governance and corporate social responsibility (CSR): the moderating roles of attainment discrepancy and organization slack. Corporate Governance: An International Review 19(2):136-152. https://doi.org/10.1111/j.1467-8683.2010.00843.x.

Axt, Jordan R. 2018. The best way to measure explicit racial attitudes is to ask about them. Social Psychological and Personality Science 9(8):896-906.

Basu, Kunal, and Guido Palazzo. 2008. Corporate social responsibility: a process model of sensemaking. Academy of Management Review 33(1):122-136. https://doi.org/10.5465/amr.2008.27745504.

Beddewela, Eshani, and Jenny Fairbrass. 2016. Seeking legitimacy through CSR: Institutional pressures and corporate responses of multinationals in Sri Lanka. Journal of Business Ethics 136:503-522. https://doi.org/10.1007/s10551-014-2478-z.

Bergstresser, Daniel, and Thomas Philippon. 2006. CEO incentives and earnings management. Journal of Financial Economics 80(3):511-529. https://doi.org/10.1016/j.jfineco.2004.10.011. 
Boiral, Olivier, Iñaki Heras-Saizarbitoria, and Francesco Testa. 2017. SA8000 as CSR-washing? The role of stakeholder pressures. Corporate Social Responsibility and Environmental Management 24(1):57-70. https://doi.org/10.1002/csr.1391.

Bonner, Sarah E., Reid Hastie, Geoffrey B. Sprinkle, and S. Mark Young. 2000. A review of the effects of financial incentives on performance in laboratory tasks: Implications for management accounting. Journal of Management Accounting Research 12(1):19-64. https://doi.org/10.2308/jmar.2000.12.1. 19.

Boone, Christophe, Tine Buyl, Carolyn H. Declerck, and Miha Sajko. 2020. A neuroscience-based model of why and when CEO social values affect investments in corporate social responsibility. The Leadership Quarterly in press. https://doi.org/10.1016/j.leaqua.2020.101386.

Boulouta, Ioanna. 2013. Hidden connections: the link between board gender diversity and corporate social performance. Journal of Business Ethics 113:185-197. https://doi.org/10.1007/s10551-012-1293-7.

Bowen, Howard R. 2013. Social responsibilities of the businessman. Iowa City: University of Iowa Press.

Brandon, Duane M., H. Long James, Tina M. Loraas, Jennifer Mueller-Phillips, and Brian Vansant. 2014. Online instrument delivery and participant recruitment services: emerging opportunities for behavioral accounting research. Behavioral Research in Accounting 26(1):1-23. https://doi.org/10.2308/ bria-50651.

Breuer, Wolfgang, Jana A. Kollath, Astrid J. Salzmann, and Rüdiger von Nitzsch. 2016. The assessment of risk behavior: a cross-cultural analysis using the DOSPERT scale. In Behavioral finance: where do investor biases come from?, ed. Itzhak Venezia, 159-180. Singapur: World Scientific Publishing Co. https://doi.org/10.1142/9789813100091_0005.

Brieger, Steven A., Claude Francoeur, Christian Welzel, and Walid Ben-Amar. 2019. Empowering women: the role of emancipative forces in board gender diversity. Journal of Business Ethics 155:495-511. https://doi.org/10.1007/s10551-017-3489-3.

Bryant, Andrew, J. Griffin Jennfer, and Vanessa G. Perry. 2020. Mitigating climate change: a role for regulations and risk-taking. Business Strategy and the Environment 29(2):605-618. https://doi.org/ $10.1002 /$ bse. 2391 .

Business Roundtable. 2019. Statement on the purpose of a corporation. https://opportunity. businessroundtable.org/ourcommitment/. Accessed 5 Apr 2020.

Buurman, Margaretha, Josse Delfgaauw, Robert Dur, and Seth Van den Bossche. 2012. Public sector employees: risk averse and altruistic? Journal of Economic Behavior \& Organization 83(3):279-291. https://doi.org/10.1016/j.jebo.2012.06.003.

Byrne, Barbara M. 2013. Structural equation modeling with AMOS: basic concepts, applications, and programming. New York: Routledge.

Cabeza-García, Laura, Roberto Fernández-Gago, and Mariano Nieto. 2018. Do board gender diversity and director typology impact CSR reporting? European Management Review 15(4):559-575. https://doi. org/10.1111/emre.12143.

Carroll, Archie B. 1999. Corporate social responsibility: evolution of a definitional construct. Business \& Society 38(3):268-295.

Chin, Mun Kyun, Donald C. Hambrick, and Linda K. Treviño. 2013. Political ideologies of CEOs: the influence of executives' values on corporate social responsibility. Administrative Science Quarterly 58(2):197-232.

Cordeiro, James J., and Manish Tewari. 2015. Firm characteristics, industry context, and investor reactions to environmental CSR: a stakeholder theory approach. Journal of Business Ethics 130:833-849. https://doi.org/10.1007/s10551-014-2115-x.

Croson, Rachel, and Nancy Buchan. 1999. Gender and culture: International experimental evidence from trust games. American Economic Review 89(2):386-391. https://doi.org/10.1257/aer.89.2.386.

Croson, Rachel, and Uri Gneezy. 2009. Gender differences in preferences. Journal of Economic Literature 47(2):448-474. https://doi.org/10.1257/jel.47.2.448.

Dam, Lammertjan, and Bert Scholtens. 2013. Ownership concentration and CSR policy of European multinational enterprises. Journal of Business Ethics 118:117-126. https://doi.org/10.1007/s10551-0121574-1.

Davis, Mark H. 1980. A multidimensional approach to individual differences in empathy. Catalog of Selected Documents in Psychology 10:85.

Dezsö, Christian L., and David G. Ross. 2012. Does female representation in top management improve firm performance? A panel data investigation. Strategic Management Journal 33(9):1072-1089. https:// doi.org/10.1002/smj.1955. 
Dickson, Marsha A., and Rita K. Chang. 2015. Apparel manufacturers and the business case for social sustainability: 'World class' CSR and business model innovation. Journal of Corporate Citizenship 57:55-72.

Dietz, Joerg, and Emmanuelle P. Kleinlogel. 2014. Wage cuts and managers' empathy: how a positive emotion can contribute to positive organizational ethics in difficult times. Journal of Business Ethics 119:461-472. https://doi.org/10.1007/s10551-013-1836-6.

Dunlap, Riley E., and Kent D. Van Liere. 1978. A proposed measuring instrument and preliminary results: the 'new environmental paradigm. Journal of Environmental Education 9(4):10-19. https://doi.org/ 10.1080/00958964.1978.10801875.

Eagly, Alice H. 1987. Sex differences in social behavior: a social-role interpretation. Hillsdale: Lawrence Erlbaum.

Eagly, Alice H., and Wendy Wood. 1991. Explaining sex differences in social behavior: a meta-analytic perspective. Personality and Social Psychology Bulletin 17(3):306-315.

Ebenbach, David H., Colleen F. Moore, and S.A. Parsil. 1998. Internally and externally motivated environmental attitudes. Chicago. Paper presented at the Annual Convention of the Midwestern Psychological Association.

Eckel, Catherine C., and Philip J. Grossman. 2002. Sex differences and statistical stereotyping in attitudes toward financial risk. Evolution and Human Behavior 23(4):281-295. https://doi.org/10.1016/S10905138(02)00097-1.

Embrey, Lori L., and Jonathan J. Fox. 1997. Gender differences in the investment decision-making process. Financial Counseling and Planning 8(2):33-40.

Espahbodi, Linda, Reza Espahbodi, Norma Juma, and Amy Westbrook. 2019. Sustainability priorities, corporate strategy, and investor behavior. Review of Financial Economics 37(1):149-167. https://doi. org/10.1002/rfe.1052.

Fabrizi, Michele, Christine Mallin, and Giovanna Michelon. 2014. The role of CEO's personal incentives in driving corporate social responsibility. Journal of Business Ethics 124:311-326. https://doi.org/10. 1007/s10551-013-1864-2.

Faccio, Mara, Maria-Teresa Marchica, and Roberto Mura. 2016. CEO gender, corporate risk-taking, and the efficiency of capital allocation. Journal of Corporate Finance 39:193-209. https://doi.org/10. 1016/j.jcorpfin.2016.02.008.

Fetchenhauer, Detlef, and Percy A. Rohde. 2002. Evolutionary personality psychology and victimology: Sex differences in risk attitudes and short-term orientation and their relation to sex differences in victimizations. Evolution and Human Behavior 23(4):233-244. https://doi.org/10.1016/S10905138(01)00104-0.

Flammer, Caroline. 2018. Competing for government procurement contracts: the role of corporate social responsibility. Strategic Management Journal 39(5):1299-1324. https://doi.org/10.1002/smj.2767.

Flammer, Caroline, and Ioannis Ioannou. 2021. Strategic management during the financial crisis: how firms adjust their strategic investments in response to credit market disruptions. Strategic Management Journal 42(7):1275-1298. https://doi.org/10.1002/smj.3265.

Flammer, Caroline, Bryan Hong, and Dylan Minor. 2019. Corporate governance and the rise of integrating corporate social responsibility criteria in executive compensation: Effectiveness and implications for firm outcomes. Strategic Management Journal 40(7):1097-1122. https://doi.org/10.1002/smj.3018.

Forte, Almerinda. 2004. Antecedents of managers moral reasoning. Journal of Business Ethics 51:315-347. https://doi.org/10.1023/B:BUSI.0000032501.59580.33.

Francis, Bill, Hasan Iftekhar, Jong C. Park, and Qiang Wu. 2015. Gender differences in financial reporting decision making: evidence from accounting conservatism. Contemporary Accounting Research 32(3):1285-1318. https://doi.org/10.1111/1911-3846.12098.

Francoeur, Claude, Réal Labelle, and Bernard Sinclair-Desgagné. 2008. Gender diversity in corporate governance and top management. Journal of Business Ethics 81:83-95. https://doi.org/10.1007/s10551007-9482-5.

Francoeur, Claude, Réal Labelle, Souha Balti, and Saloua E. Bouzaidi. 2019. To what extent do gender diverse boards enhance corporate social performance? Journal of Business Ethics 155:343-357. https:// doi.org/10.1007/s10551-017-3529-z.

Gartenberg, Claudine, and George Serafeim. 2019. 181 top CEOs have realized companies need a purpose beyond profit. Harvard Business Review. https://hbr.org/2019/08/181-top-ceos-have-realizedcompanies-need-a-purpose-beyond-profit. Accessed 12 Dec 2020.

Gilligan, Carol. 1977. In a different voice: Women's conceptions of self and of morality. Harvard Educational Review 47(4):481-517. https://doi.org/10.17763/haer.47.4.g6167429416hg510.

Gilligan, Carol. 1982. In a different voice. Cambridge: Harvard University Press. 
Glass, Christy, and Alison Cook. 2018. Do women leaders promote positive change? Analyzing the effect of gender on business practices and diversity initiatives. Human Resource Management 57(4):823-837. https://doi.org/10.1002/hrm.21838.

Glass, Christy, Alison Cook, and Alicia R. Ingersoll. 2016. Do women leaders promote sustainability? Analyzing the effect of corporate governance composition on environmental performance. Business Strategy and the Environment 25(7):495-511. https://doi.org/10.1002/bse.1879.

Grewal, Jody, Georgios Serafeim, and Aaron S. Yoon. 2016. Shareholder activism on sustainability issues. Harvard Business School Working Paper, No. 17-003. http://nrs.harvard.edu/urn-3:HUL.InstRepos: 27864360. Accessed 08 February 2020.

Hafenbrädl, Sebastian, and Daniel Waeger. 2017. Ideology and the micro-foundations of CSR: why executives believe in the business case for CSR and how this affects their CSR engagements. Academy of Management Journal 60(4):1582-1606. https://doi.org/10.5465/amj.2014.0691.

Hafsi, Taieb, and Gokhan Turgut. 2013. Boardroom diversity and its effect on social performance: conceptualization and empirical evidence. Journal of Business Ethics 112:463-479. https://doi.org/10.1007/ s10551-012-1272-z.

Haney, Aoife B., Jenny Pope, and Zoe Arden. 2020. Making it personal: developing sustainability leaders in business. Organization \& Environment 33(2):155-174.

Hang, Markus, Jerome Geyer-Klingeberg, and Andreas W. Rathgeber. 2019. It is merely a matter of time: a meta-analysis of the causality between environmental performance and financial performance. Business Strategy and the Environment 28(2):257-273. https://doi.org/10.1002/bse.2215.

Hannah, Sean T., Peter L. Jennings, Dustin Bluhm, Ann C. Peng, and John M. Schaubroeck. 2014. Duty orientation: Theoretical development and preliminary construct testing. Organizational Behavior and Human Decision Processes 123(2):220-238. https://doi.org/10.1016/j.obhdp.2013.10.007.

Harjoto, Maretno, Indrarini Laksmana, and Robert Lee. 2015. Board diversity and corporate social responsibility. Journal of Business Ethics 132(4):641-660. https://doi.org/10.1007/s10551-014-23430 .

Harvey, Michael, and Charlotte Pearson. 2018. Exploring the impacts of shareholder activism on sustainability. SustainAbility and the Luc Hoffmann Institute. https://www.sustainability.com/globalassets/ sustainability.com/thinking/pdfs/sa-shareholderactivism-1.pdf. Accessed 10 Feb 2021.

Henderson, Rebecca M. 2018. More and more CEOs are taking their social responsibility seriously. Harvard Business Review. https://hbr.org/2018/02/more-and-more-ceos-are-taking-their-socialresponsibility-seriously. Accessed 12 Aug 2020.

Highhouse, Scott, Christopher D. Nye, Don C. Zhang, and Thaddeus B. Rada. 2017. Structure of the Dospert: Is there evidence for a general risk factor? Journal of Behavioral Decision Making 30(2):400-406. https://doi.org/10.1002/bdm.1953.

Hillman, Amy J., Albert A. Cannella, and Ramona L. Paetzold. 2000. The resource dependence role of corporate directors: strategic adaptation of board composition in response to environmental change. Journal of Management Studies 37(2):235-256. https://doi.org/10.1111/1467-6486.00179.

Hoffmann, Werner H., and Lukas Meusburger. 2018. How CEO values and TMT diversity jointly influence the corporate strategy making process. Schmalenbach Business Review 70:149-187. https://doi.org/ 10.1007/s41464-017-0042-y.

Hoyle, Rick H., and Nisha C. Gottfredson. 2015. Sample size considerations in prevention research applications of multilevel modeling and structural equation modeling. Prevention Science 16(7):987-996. https://doi.org/10.1007/s11121-014-0489-8.

Huang, Jiekun, and Darren J. Kisgen. 2013. Gender and corporate finance: are male executives overconfident relative to female executives? Journal of Financial Economics 108(3):822-839. https://doi.org/ 10.1016/j.jfineco.2012.12.005.

Huang, Lingbo, and Zahra Murad. 2020. Feedback spillover effect on competitiveness across unrelated tasks. Behavioral Research in Accounting 32(1):69-85. https://doi.org/10.2308/bria-52583.

Ibrahim, Nabil, John Angelidis, and Igor M. Tomic. 2009. Managers' attitudes toward codes of ethics: are there gender differences? Journal of Business Ethics 90(3):343-353. https://doi.org/10.1007/s10551010-0428-y.

Jaffee, Sara, and Janet S. Hyde. 2000. Gender differences in moral orientation: a meta-analysis. Psychological Bulletin 126(5):703-726. https://doi.org/10.1037/0033-2909.126.5.703.

Johnson, Joseph A., Steve G. Sutton, and Jochen C. Theis. 2020a. Prioritizing sustainability issues: insights from corporate managers about key decision-makers, reporting models, and stakeholder communications. Accounting and the Public Interest 20(1):28-60. https://doi.org/10.2308/API-19-018. 
Johnson, Joseph A., Jochen C. Theis, Adam Vitalis, and Donald Young. 2020b. The influence of firms' emissions management strategy disclosures on investors' valuation judgments. Contemporary Accounting Research 37(2):642-664. https://doi.org/10.1111/1911-3846.12545.

Kahai, Surinder S., and Randolph B. Cooper. 2003. Exploring the core concepts of media richness theory: the impact of cue multiplicity and feedback immediacy on decision quality. Journal of Management Information Systems 20(1):263-299. https://doi.org/10.1080/07421222.2003.11045754.

Kato, Takao, and Naomi Kodama. 2018. The effect of corporate social responsibility on gender diversity in the workplace: econometric evidence from Japan. British Journal of Industrial Relations 56(1):99-127. https://doi.org/10.1111/bjir.12238.

Kortenkamp, Katherine V., and Collee F. Moore. 2001. Ecocentrism and anthropocentrism: moral reasoning about ecological commons dilemmas. Journal of Environmental Psychology 21(3):261-272. https://doi.org/10.1006/jevp.2001.0205.

Kunz, Jennifer. 2020. Corporate social responsibility and employees motivation-broadening the perspective. Schmalenbach Business Review 72:159-191. https://doi.org/10.1007/s41464-020-00089-9.

Levi, Maurice D., Kai Li, and Feng Zhang. 2008. Mergers and acquisitions: the role of gender. Working Paper. https://doi.org/10.2139/ssrn.1123735.

Li, Weiwei, Wang Haixia, Xie Xiaofei, and Jian Li. 2019. Neural mediation of greed personality trait on economic risk-taking. Elife 8:e45093. https://doi.org/10.7554/eLife.45093.001.

Lin-Hi, Nick, and Karsten Müller. 2013. The CSR bottom line: preventing corporate social irresponsibility. Journal of Business Research 66(10):1928-1936. https://doi.org/10.1016/j.jbusres.2013.02.015.

Luo, Xiaowei R., Wang Danqing, and Jianjun Zhang. 2017. Whose call to answer: Institutional complexity and firms' CSR reporting. Academy of Management Journal 60(1):321-344. https://doi.org/10.5465/ amj.2014.0847.

MacCallum, Robert C., Michael W. Browne, and Hazuki M. Sugawara. 1996. Power analysis and determination of sample size for covariance structure modeling. Psychological Methods 1(2):130-149. https://doi.org/10.1037/1082-989X.1.2.130.

Makri, Marianna Peter J.Lane, and Luis R. Gomez-Mejia. 2006. CEO incentives, innovation, and performance in technology-intensive firms: a reconciliation of outcome and behavior-based incentive schemes. Strategic Management Journal 27(11):1057-1080. https://doi.org/10.1002/smj.560.

Markiewicz, Łukasz, and Elke U. Weber. 2013. DOSPERT's gambling risk-taking propensity scale predicts excessive stock trading. Journal of Behavioral Finance 14(1):65-78. https://doi.org/10.1080/ 15427560.2013.762000.

McWilliams, Abagail, Donald S. Siegel, and Patrick M. Wright. 2006. Corporate social responsibility: strategic implications. Journal of Management Studies 43(1):1-18. https://doi.org/10.1111/j.14676486.2006.00580.x.

Michelon, Giavanna, and Michelle Rodrigue. 2015. Demand for CSR: Insights from shareholder proposals. Social and Environmental Accountability Journal 35(3):157-175. https://doi.org/10.1080/0969160X. 2015.1094396.

Minor, Dylan, and John Morgan. 2011. CSR as reputation insurance: primum non nocere. California Management Review 53(3):40-59.

Mohan, Nancy J., and Carl R. Chen. 2004. Are IPOs priced differently based upon gender? The Journal of Behavioral Finance 5(1):57-65. https://doi.org/10.1207/s15427579jpfm0501_6.

Morgado, Fabiane F.R., Juliana F.F. Meireles, Clara M. Neves, Ana C.S. Amaral, and Maria E.C. Ferreira. 2017. Scale development: ten main limitations and recommendations to improve future research practices. Psychological Assessment Review 30(3):1-20. https://doi.org/10.1186/s41155-016-0057-1.

Moser, Donald V., and Patrick R. Martin. 2012. A broader perspective on corporate social responsibility research in accounting. The Accounting Review 87(3):797-806. https://doi.org/10.2308/accr-10257.

Nelling, Edward, and Elizabeth Webb. 2009. Corporate social responsibility and financial performance: the "virtuous circle" revisited. Review of Quantitative Finance and Accounting 32(2):197-209. https:// doi.org/10.1007/s11156-008-0090-y.

Nunnally, Jum C. 1967. Psychometric theory. New York: McGraw-Hill.

Perrault, Elise, and Cynthia Clark. 2015. Environmental shareholder activism: considering status and reputation in firm responsiveness. Organization \& Environment 29(2):194-211.

Petrenko, Oleg V., Federico Aime, Jason Ridge, and Aaron Hill. 2016. Corporate social responsibility or CEO narcissism? CSR motivations and organizational performance. Strategic Management Journal 37(2):262-279. https://doi.org/10.1002/smj.2348.

Pierce, Jon L., Donald G. Gardner, and Courtney Crowley. 2016. Organization-based self-esteem and wellbeing: empirical examination of a spillover effect. European Journal of Work and Organizational Psychology 25(2):181-199. https://doi.org/10.1080/1359432X.2015.1028377. 
Porter, Terry, and Patti Miles. 2013. CSR longevity: evidence from long-term practices in large corporations. Corporate Reputation Review 16(4):313-340. https://doi.org/10.1057/crr.2013.17.

Powell, Melanie, and David Ansic. 1997. Gender differences in risk behaviour in financial decision-making: an experimental analysis. Journal of Economic Psychology 18(6):605-628. https://doi.org/10. 1016/S0167-4870(97)00026-3.

Ratzinger-Sakel, Nicole V.S., and Jochen Theis. 2019. Does considering key audit matters affect auditor judgment performance? Corporate Ownership \& Control 17(1):196-210. https://doi.org/10.22495/ cocv17i1siart4.

Sajko, Miha, Christopher Boone, and Tine Buyl. 2021. CEO greed, corporate social responsibility, and organizational resilience to systemic shocks. Journal of Management 47(4):957-992.

Shiu, Yung-Ming, and Shou-Lin Yang. 2017. Does engagement in corporate social responsibility provide strategic insurance-like effects? Strategic Management Journal 38(2):455-470. https://doi.org/ 10.1002/smj.2494.

Smith, Nina. 2018. Gender quotas on boards of directors. IZA World of Labor. https://wol.iza.org/articles/ gender-quotas-on-boards-of-directors/long. Accessed 15 Aug 2020.

So, Johnny C.F., and Narasimha Bolloju. 2005. Explaining the intentions to share and reuse knowledge in the context of IT service operations. Journal of Knowledge Management 9(6):30-41. https://doi.org/ $10.1108 / 13673270510629945$.

Stewart, Neil. 2018. Are women better investors than men? https://www.wbs.ac.uk/news/are-womenbetter-investors-than-men/. Accessed 12 Sept 2020.

Terjesen, Siri, Ruth Sealy, and Val Singh. 2009. Women directors on corporate boards: a review and research agenda. Corporate Governance: An International Review 17(3):320-337. https://doi.org/10. 1111/j.1467-8683.2009.00742.x.

Van Raaij, Erik M., and Jeroen J.L. Schepers. 2008. The acceptance and use of a virtual learning environment in China. Computers \& Education 50(3):838-852. https://doi.org/10.1016/j.compedu.2006.09. 001 .

Venkatesh, Viswanath, and Fred D. Davis. 2000. A theoretical extension of the technology acceptance model: four longitudinal field studies. Management Science 46(2):186-204. https://doi.org/10.1287/ mnsc.46.2.186.11926.

Wally, Stefan, and J. Robert Baum. 1994. Personal and structural determinants of the pace of strategic decision making. Academy of Management Journal 37(4):932-956. https://doi.org/10.5465/256605.

Walter, Sheryl L., Scott E. Seibert, Daniel Goering, and Ernest H. O'Boyle. 2019. A tale of two sample sources: do results from online panel data and conventional data converge? Journal of Business and Psychology 34(4):425-452. https://doi.org/10.1007/s10869-018-9552-y.

Wang, Jia, and H. Dudley Dewhirst. 1992. Boards of directors and stakeholder orientation. Journal of Business Ethics 11(2):115-123. https://doi.org/10.1007/BF00872318.

Wang, Heli, Li Tong, Riki Takeuchi, and Gerard George. 2016. Corporate social responsibility: an overview and new research directions. Academy of Management Journal 59(2):534-544. https://doi.org/10. 5465/amj.2016.5001.

Weber, Elke U., Ann-Renée Blais, and Nancy E. Betz. 2002. A domain-specific risk-attitude scale: measuring risk perceptions and risk behaviors. Journal of Behavioral Decision Making 15(4):263-290. https://doi.org/10.1002/bdm.414.

Werther, William B., Jr, and David Chandler. 2005. Strategic corporate social responsibility as global brand insurance. Business Horizons 48(4):317-324. https://doi.org/10.1016/j.bushor.2004.11.009.

Westland, J. Christopher. 2010. Lower bounds on sample size in structural equation modeling. Electronic commerce research and applications 9(6):476-487. https://doi.org/10.1016/j.elerap.2010.07.003.

Wolf, Erika J., Kelly M. Harrington, Shaunna L. Clark, and Mark W. Miller. 2013. Sample size requirements for structural equation models: an evaluation of power, bias, and solution propriety. Educational and Psychological Measurement 73(6):913-934.

Wu, Joseoph, and Hoi Y. Cheung. 2014. Confirmatory factor analysis of DOSPERT scale with Chinese university students. Psychological Reports 114(1):185-197.

Yoo, Youngjin, and Maryam Alavi. 2001. Media and group cohesion: relative influences on social presence, task participation, and group consensus. MIS quarterly 25(3):371-390. https://doi.org/10.2307/ 3250922. 